Florida International University FIU Digital Commons

$3-27-2014$

\title{
Investigating Miami English-Spanish Bilinguals' Treatment of English Deictic Verbs of Motion
}

Erica Verde

Florida International University, erica.verde@gmail.com

DOI: $10.25148 /$ etd.FI14040892

Follow this and additional works at: https://digitalcommons.fiu.edu/etd

Part of the English Language and Literature Commons, First and Second Language Acquisition $\underline{\text { Commons, }} \underline{\text { Modern Languages Commons, and the Psycholinguistics and Neurolinguistics }}$ Commons

\section{Recommended Citation}

Verde, Erica, "Investigating Miami English-Spanish Bilinguals' Treatment of English Deictic Verbs of Motion" (2014). FIU Electronic Theses and Dissertations. 1229.

https://digitalcommons.fiu.edu/etd/1229

This work is brought to you for free and open access by the University Graduate School at FIU Digital Commons. It has been accepted for inclusion in FIU Electronic Theses and Dissertations by an authorized administrator of FIU Digital Commons. For more information, please contact dcc@fiu.edu. 


\section{FLORIDA INTERNATIONAL UNIVERSITY}

Miami, Florida

\section{INVESTIGATING MIAMI ENGLISH-SPANISH BILINGUALS' TREATMENT OF ENGLISH DEICTIC VERBS OF MOTION}

A thesis submitted in partial fulfillment of the requirements for the degree of

\section{MASTER OF ARTS}

in

LINGUISTICS

by

Erica L. Verde 
To: Dean Kenneth G. Furton

College of Arts and Sciences

This thesis, written by Erica L. Verde, and entitled Investigating Miami English-Spanish Bilinguals' Treatment of English Deictic Verbs of Motion, having been approved in respect to style and intellectual content, is referred to you for judgment.

We have read this thesis and recommend that it be approved.

Melissa Baralt

Feryal Yavas

Virginia Mueller Gathercole, Major Professor

Date of Defense: March 27, 2014

The thesis of Erica L. Verde is approved.

Dean Kenneth G. Furton

College of Arts and Sciences

Dean Lakshmi N. Reddi

University Graduate School

Florida International University, 2014 
(C) Copyright 2014 by Erica L. Verde

All rights reserved. 


\section{ACKNOWLEDGMENTS}

Bringing this thesis to fruition has been a challenging, extremely rewarding personal and professional experience from its conception. I would like to express the most profound gratitude to Dr. Virginia Mueller Gathercole for her unwavering support and ever-patient direction throughout this process. Dr. Feryal Yavaş provided insightful feedback and guidance on so many aspects of this project, for which I am very grateful. As always, Dr. Melissa Baralt was a constant source of encouragement and inspiration.

I would like to deeply thank and recognize Elmo Lugo, Angie Gutierrez, Hilda Aguilera and the entire staff of the Video Production Services at Florida International University for their expertise and the numerous hours dedicated to helping me create the highest quality stimuli for this thesis. I would also like to thank Nelson and Mary Cadahia and family of Dixon costumes and Adriana Bonilla for their generous contributions. To Hussain, Jake, Jehan, Yaobin, Josh, David, and Christopher: a linguist could not ask for better friends - thank you for your enthusiasm and genuine care. 


\section{DEDICATION}

This thesis is dedicated to Mani, Abuelo and Abuela, without whose courage to come to a unknown land, allowed to bring with them only love and the resolve to persevere, made it possible for me to go chase unimaginable dreams and to take from this world the limitless opportunities it has to offer.

Los extrañamos 


\section{ABSTRACT OF THE THESIS \\ INVESTIGATING MIAMI ENGLISH-SPANISH BILINGUALS' TREATMENT OF ENGLISH DEICTIC VERBS OF MOTION}

by

Erica L. Verde

Florida International University, 2014

Miami, Florida

Professor Virginia Mueller Gathercole, Major Professor

This investigation focused on the treatment of English deictic verbs of motion by Spanish-English bilinguals in Miami. Although English and Spanish share significant overlap of the spatial deixis system, they diverge in important aspects. It is not known how these verbs are processed by bilinguals. Thus, this study examined Spanish-English bilinguals' interpretation of the verbs come, go, bring, and take in English.

Forty-five monolingual English speakers and Spanish-English bilinguals participated. Participants were asked to watch video clips depicting motion events and to judge the acceptability of accompanying narrations spoken by the actors in the videos.

Analyses showed that, in general, monolinguals and bilinguals patterned similarly across the deictic verbs come, bring, go and take. However, they did differ in relation to acceptability of word order for verbal objects. Also, bring was highly accepted by all language groups across all goal paths, possibly suggesting an innovation in its use. 


\section{TABLE OF CONTENTS}

CHAPTER

PAGE

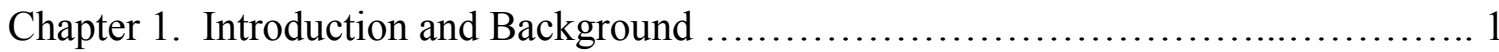

Chapter 2. Research Design and Methodology ..........................................

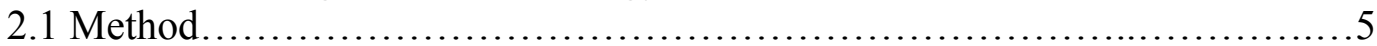

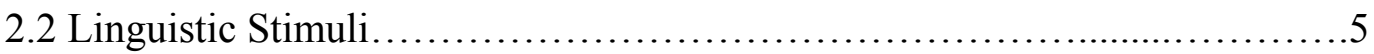

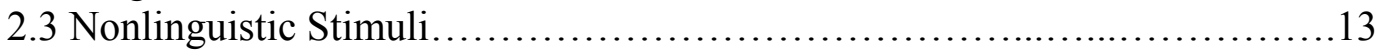

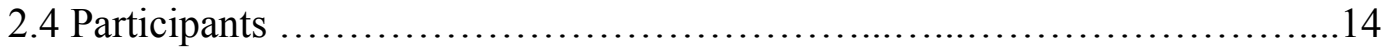

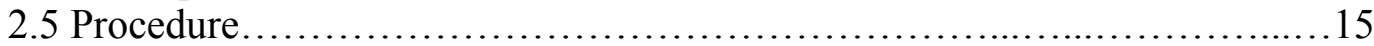

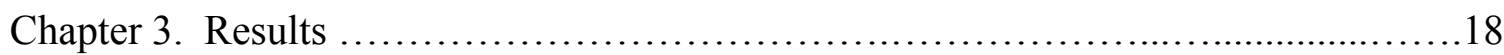

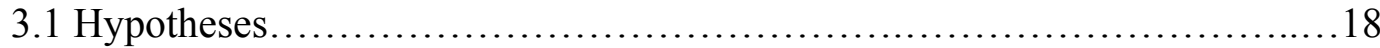

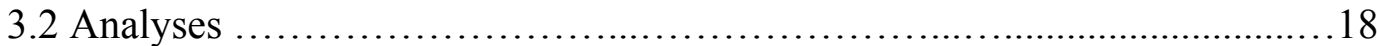

3.2.1 Main Analyses of Variance with all variables............................... 18

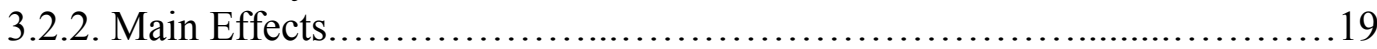

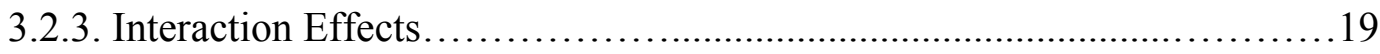

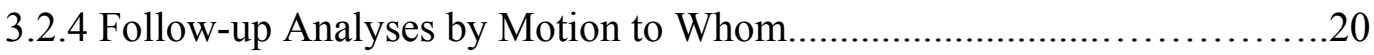

3.2.5 Follow-up Analyses by Motion to Whom

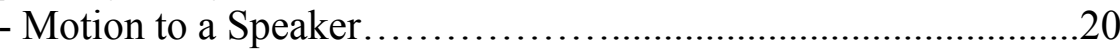

3.2.6 Follow-up Analyses by Motion to Whom

- Motion to a Speaker by Verb Type.................................................21

3.2.7 Follow-up Analyses by Motion to Whom - Motion to an Addressee..................................................................22

3.2.8 Follow-up Analyses by Motion to Whom

- Motion to an Addressee by Verb Type ...........................................23

3.2.9 Follow-up Analyses by Motion to Whom - Motion to a Third Party...............................................................24

3.2.10 Follow-up Analyses by Motion to Whom - Motion to a Third Party by Verb Type ........................................25

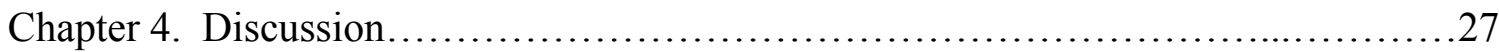

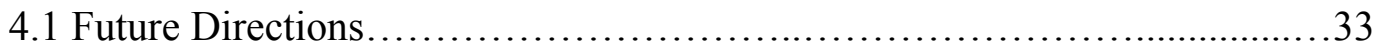

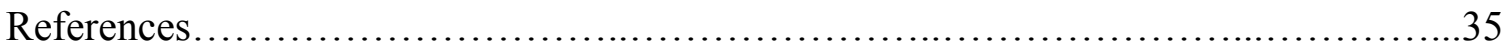

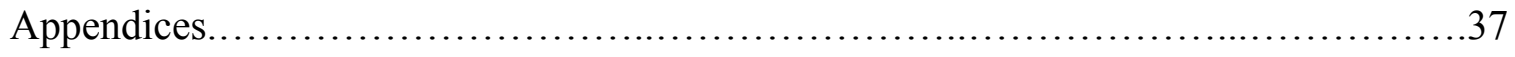


Table 1 Deixis of Verbs of Motion in English and Spanish..........................4

Table 2.2.a Linguistic Stimuli across the verb come............................................

Table 2.2.b Linguistic Stimuli across the verb bring............................... 8

Table 2.2.c Linguistic Stimuli across the verb go................................ 9

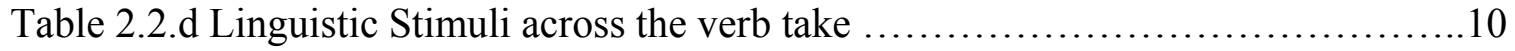

Table 2.2.e Linguistic Stimuli across the verb give................................11

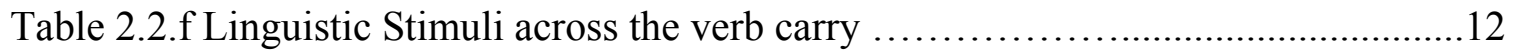

Table 2.2.g Linguistic Stimuli across the verb deliver............................. 12 
Chapter 1. Introduction and Background

The focus of the following investigation is the treatment of English deictic verbs of motion by English-Spanish bilinguals in the Miami context. Deictic elements "convey semantic and pragmatic meaning as to the relationship between the speaker, addressee or a third party and any events described in terms of spatial and temporal facets" (Clark and Garnica, 1974). Deixis is generally accepted to encompass three independent types:

person, time and space. It should be noted that in many languages the distinction between these three types is not clear-cut, and multiple aspects of each must be taken into consideration in order to effectively convey and or interpret the intended meaning (Richardson, 1996). Place or spatial deixis refers to words that derive their meaning according to the relation between the position of the speaker and addressee in space at the time of the discursive act.

The present investigation will focus primarily on a special category of deictic spatial elements called "deictic verbs of motion". The use of motion verbs is quite complex and requires cognitive and pragmatic resources in order to interpret (Fillmore, 1971); motion verbs make use of all of the deictic components (person, time and space): to effectively interpret their use, the listener must be attuned to the speaker's position in space in addition to the time of speech as well as the direction of movement. This direction of movement may be oriented in any number or ways and may even be culturally bound (Clark \& Garnica, 1974).

In Fillmore (1981), the constraints regarding the deictic verbs come and go are delineated as such: 
"Come" and "go" indicate the location of either the speaker or the addressee at either coding time or reference time or toward the location of the home base of either the speaker or the addressee at reference time. "Come" and "bring" also indicate motion at reference time which his in the company of either the speaker or the addressee. "Come" and "bring" also indicate in discourse in which neither the speaker nor the addressee figures as a character, motion toward a place taken as the subject of the narrative toward the location of the central character at reference time, or toward the place which is the central character's home base at reference time.

Additionally, Fillmore (1971) addresses the verbs bring and take as the causative counterparts to come and $g o$, respectively; the treatment of these as verbs with unique deictic properties is brief, as bring and take generally pattern in much the same way that come and go do (p. 59). In his seminal works on deixis, Fillmore gives thorough explications of various types of deixis including metaphorical and what he terms the "home-base" paradigm, namely where one can project the deictic center onto a differing location, a location not corresponding to the relevant person's location at coding or reference time. As this investigation only focuses on deictic scenarios where all parties share the same communicative space, I will only be concentrating on elements germane to this, what Fillmore called "person-deictically anchored discourse" (1971, p.54).

Likewise, the deictic verbs of motion of Spanish, venir, traer, ir and llevar, whose translational equivalents in English are come, bring, go and take, respectively, have enjoyed a comprehensive analysis via both traditional grammar analyses and modern 
pragmatic study (Burdach et al., 1984, 1985; Cano, 1979; Moreno, 1985; Molho, 1968; Richardson, 1996; Rodríguez-Izquierdo y Gavala, 1976). Miami, in a linguistic sense, is a complex American city: many languages other than English, especially Spanish, are spoken by a significant number of its inhabitants. The population in question is also unique in that speakers are educated predominantly in English but may have significant access to Spanish through home and community use (De Houwer, 1995). The pervasiveness of the bilingual condition in Miami has even led to recognition of Spanish as an official language on a par with English. Little, if any, research has been undertaken to specifically analyze the way English-Spanish bilinguals' use and accept the usage of English deictic elements. Although deixis has been described and analyzed extensively by linguists and grammarians in the constituent languages of this bilingual pairing, it has not been examined in terms of the dynamic environment of bilingual interaction. This phenomenon is of particular linguistic interest because of the fact that the Spanish and English deictic systems share many features while diverging in certain conditions.

An example that elegantly demonstrates the differences between the aforementioned deictic verbs of motion in English and Spanish is that of answering the door when someone is knocking. In English, if a person were to knock at one's door, one might reply, "I'm coming." and the corresponding movement would be that of the speaker toward the addressee. The same scenario, in Spanish, would prompt the speaker's reply of "(ya) Voy."; voy translates directly as "I am going." in English. 
Table 1: Deixis of Verbs of Motion in English and Spanish

\begin{tabular}{|c|c|c|}
\hline & English & Spanish \\
\hline $\begin{array}{l}\text { Movement of addressee } \\
\text { toward the speaker's } \\
\text { position (at time of speech } \\
\text { act or goal location)* }\end{array}$ & $\begin{array}{l}\text { Come/Bring } \\
\text { "Come and bring the cake" }\end{array}$ & $\begin{array}{l}\text { Come/Bring; Venir/Traer } \\
\text { "Ven y trae la torta" } \\
\text { Come ( } 2^{\text {nd }} \text { person } \\
\text { imperative) and bring ( } 2^{\text {nd }} \\
\text { person imperative) the cake }\end{array}$ \\
\hline $\begin{array}{l}\text { Movement of speaker } \\
\text { toward the addressee's } \\
\text { position (at time of speech } \\
\text { act or goal location)* }\end{array}$ & $\begin{array}{l}\text { Come/Bring } \\
\text { "I will come and bring the } \\
\text { cake" }\end{array}$ & $\begin{array}{l}\text { Go/Take; Ir/Llevar } \\
\text { "Iré y llevaré la torta" } \\
\text { Go }\left(1^{\text {st }} \text { person future }\right) \text { and } \\
\text { take }\left(1^{\text {st }} \text { person future }\right) \text { the } \\
\text { cake }\end{array}$ \\
\hline $\begin{array}{l}\text { Movement of the speaker to } \\
\text { a location different from } \\
\text { the addressee's current or } \\
\text { goal location* }\end{array}$ & $\begin{array}{l}\text { Go/Take } \\
\text { "I will go to her house and } \\
\text { take the cake" }\end{array}$ & $\begin{array}{l}\text { Go/Take; Ir/Llevar } \\
\text { "Iré a su casa y llevaré la } \\
\text { torta" } \\
\text { Go }\left(1^{\text {st }} \text { person future }\right) \text { to her } \\
\text { house and take }\left(1^{\text {st }} \text { person }\right. \\
\text { future }) \text { the cake }\end{array}$ \\
\hline
\end{tabular}

* All scenarios are from the speaker's perspective.

As a result of the divergence in deictic verb usage between English and Spanish, it is worthwhile to examine how English-Spanish bilinguals treat deixis in English. What patterns of influence do these systems have on each other, if at all, within the context of the bilingual speaker? In what ways do they differ from monolinguals in their usage of the deictic verbs of motion bring, take, go and come if they do in fact differ? It is the aim of the current study to shed more light on this question. 
Chapter 2. Research Design and Methodology

\subsection{Method}

The investigation tested the judgments of the deictic motion events involving come, go, bring and take by monolingual English and early and later-acquiring SpanishEnglish bilinguals. Participants were tasked with watching a series of short video clips and making judgments after each about the clip's acceptability using a Likert scale.

\section{$\underline{2.2 \text { Linguistic Stimuli }}$}

The four experimental verbs (come, go, bring and take) and three non-target verbs (receive, deliver and carry) were distributed along six motion paths (motion from speaker to addressee, motion from addressee to speaker, motion from speaker to a third person, motion from a third person to a speaker, motion from an addressee to a third person and motion from third person to an addressee). For the target verbs, each path and verb combination was further divided into two constituent presentations: a syntactic construction where the patient came before the recipient and the other where the recipient came before the patient. This design yielded forty-eight target trials and 24 nontarget trials as depicted in Tables 2.2.a-g. In theory, the non-target items would have yielded 36 trials (six motion paths across three verbs and two object orders) but for the verbs deliver and carry, the presentation where the recipient preceded the patient was judged by several native English speakers to be unnatural. Thus, only the patient-first ordering was retained. 
The roles of the three actors (speaker, addressee and third person) were counterbalanced in three different orders such that each actor portrayed each of the three roles a total of sixteen times for the target trials and eight times for the non-target trials. 
Table 2.2.a Linguistic Stimuli across the verb come

\begin{tabular}{|c|c|c|c|c|c|c|}
\hline & \multicolumn{6}{|c|}{ Movement from } \\
\hline & $\begin{array}{l}\text { Speaker to } \\
\text { Hearer }\end{array}$ & $\begin{array}{l}\text { Hearer to } \\
\text { Speaker }\end{array}$ & $\begin{array}{l}3^{\text {rd }} \text { person to } \\
\text { speaker }\end{array}$ & $\begin{array}{l}3^{\text {rd }} \text { Person } \\
\text { to } \\
\text { addressee }\end{array}$ & $\begin{array}{l}\text { Speaker to } \\
3^{\text {rd }} \text { person }\end{array}$ & $\begin{array}{l}\text { Hearer to } \\
3^{\text {rd }} \text { Person }\end{array}$ \\
\hline \multirow[t]{2}{*}{ Come } & $\begin{array}{l}\text { Hey Oscar, } \\
\text { I came to } \\
\text { you with } \\
\text { the X. } \\
\text { (Cookie } \\
\text { Monster is } \\
\text { Speaker; } \\
\text { Oscar is } \\
\text { addressee; } \\
\text { movement } \\
\text { from } \\
\text { Cookie } \\
\text { Monster to } \\
\text { Oscar) }\end{array}$ & $\begin{array}{l}\text { Hey Big } \\
\text { Bird, you } \\
\text { came to me } \\
\text { with the X. } \\
\text { (Oscar is } \\
\text { speaker; } \\
\text { Big Bird is } \\
\text { addressee; } \\
\text { movement } \\
\text { from Big } \\
\text { Bird to } \\
\text { Oscar) }\end{array}$ & $\begin{array}{l}\text { Hey Cookie } \\
\text { Monster, } \\
\text { Oscar came } \\
\text { to me with } \\
\text { the X. } \\
\text { (Big Bird is } \\
\text { Speaker; } \\
\text { Cookie } \\
\text { Monster is } \\
\text { addressee; } \\
\text { movement } \\
\text { from Oscar } \\
\text { to Big Bird) }\end{array}$ & $\begin{array}{l}\text { Hey Oscar, } \\
\text { Big Bird } \\
\text { came to } \\
\text { you with } \\
\text { the X. } \\
\text { (Cookie } \\
\text { Monster is } \\
\text { Speaker; } \\
\text { Oscar is } \\
\text { addressee; } \\
\text { movement } \\
\text { from Big } \\
\text { Bird to } \\
\text { Oscar) }\end{array}$ & $\begin{array}{l}\text { Hey Cookie } \\
\text { Monster, I } \\
\text { came to } \\
\text { Oscar with } \\
\text { the X. } \\
\text { (Big Bird } \\
\text { is Speaker; } \\
\text { Cookie } \\
\text { Monster is } \\
\text { addressee; } \\
\text { movement } \\
\text { from Big } \\
\text { Bird to } \\
\text { Oscar) }\end{array}$ & $\begin{array}{l}\text { Hey Oscar, } \\
\text { you came to } \\
\text { Big Bird } \\
\text { with the X. } \\
\text { (Cookie } \\
\text { Monster is } \\
\text { Speaker; } \\
\text { Oscar is the } \\
\text { addressee; } \\
\text { movement } \\
\text { from Oscar } \\
\text { to Big Bird) }\end{array}$ \\
\hline & $\begin{array}{l}\text { Hey Big } \\
\text { Bird, I } \\
\text { came with } \\
\text { the X to } \\
\text { you. } \\
\text { (Oscar is } \\
\text { Speaker; } \\
\text { Big Bird is } \\
\text { addressee; } \\
\text { movement } \\
\text { from Oscar } \\
\text { to Big } \\
\text { Bird) }\end{array}$ & $\begin{array}{l}\text { Hey Oscar, } \\
\text { you came } \\
\text { with the X } \\
\text { to me. } \\
\text { (Cookie } \\
\text { Monster is } \\
\text { Speaker; } \\
\text { Oscar is } \\
\text { addressee; } \\
\text { movement } \\
\text { from Oscar } \\
\text { to Cookie } \\
\text { Monster) }\end{array}$ & $\begin{array}{l}\text { Hey Oscar, } \\
\text { Big Bird } \\
\text { came with } \\
\text { the X to me. } \\
\text { (Cookie } \\
\text { Monster is } \\
\text { Speaker; } \\
\text { Oscar is } \\
\text { addressee; } \\
\text { movement } \\
\text { from Big } \\
\text { Bird to } \\
\text { Cookie } \\
\text { Monster) }\end{array}$ & $\begin{array}{l}\text { Hey } \\
\text { Cookie } \\
\text { Monster, } \\
\text { Oscar } \\
\text { came with } \\
\text { the X to } \\
\text { you. } \\
\text { (Big Bird is } \\
\text { Speaker; } \\
\text { Cookie } \\
\text { Monster is } \\
\text { addressee; } \\
\text { movement } \\
\text { from } \\
\text { Oscar to } \\
\text { CM) }\end{array}$ & $\begin{array}{l}\text { Hey Big } \\
\text { Bird, I } \\
\text { came with } \\
\text { the X to } \\
\text { Cookie } \\
\text { Monster. } \\
\text { (Oscar is } \\
\text { speaker; } \\
\text { Big Bird is } \\
\text { addressee; } \\
\text { movement } \\
\text { from Oscar } \\
\text { to Cookie } \\
\text { Monster) }\end{array}$ & $\begin{array}{l}\text { Hey Big } \\
\text { Bird, you } \\
\text { came with } \\
\text { the X to } \\
\text { Cookie } \\
\text { Monster. } \\
\text { (Oscar is } \\
\text { speaker; } \\
\text { Big Bird is } \\
\text { addressee; } \\
\text { movement } \\
\text { from Big } \\
\text { Bird to } \\
\text { Cookie } \\
\text { Monster) }\end{array}$ \\
\hline
\end{tabular}


Table 2.2.b Linguistic Stimuli across the verb bring

\begin{tabular}{|c|c|c|c|c|c|c|}
\hline & \multicolumn{6}{|c|}{ Movement from } \\
\hline & $\begin{array}{l}\text { Speaker to } \\
\text { Hearer }\end{array}$ & $\begin{array}{l}\text { Hearer to } \\
\text { Speaker }\end{array}$ & $\begin{array}{l}3^{\text {rd }} \text { person to } \\
\text { speaker }\end{array}$ & $\begin{array}{l}3^{\text {rd }} \text { Person } \\
\text { to } \\
\text { addressee }\end{array}$ & $\begin{array}{l}\text { Speaker to } \\
3^{\text {rd }} \text { person }\end{array}$ & $\begin{array}{l}\text { Hearer to } \\
3^{\text {rd }} \text { Person }\end{array}$ \\
\hline \multirow[t]{2}{*}{ Bring } & $\begin{array}{l}\text { Hey Oscar, } \\
\text { I brought } \\
\text { you the X. } \\
\text { (Cookie } \\
\text { Monster is } \\
\text { Speaker; } \\
\text { Oscar is } \\
\text { addressee; } \\
\text { movement } \\
\text { from } \\
\text { Cookie } \\
\text { Monster to } \\
\text { Oscar) }\end{array}$ & $\begin{array}{l}\text { Hey Oscar, } \\
\text { you brought } \\
\text { me the X. } \\
\text { (Cookie } \\
\text { Monster is } \\
\text { Speaker; } \\
\text { Oscar is } \\
\text { addressee; } \\
\text { movement } \\
\text { from Oscar } \\
\text { to Cookie } \\
\text { Monster) }\end{array}$ & $\begin{array}{l}\text { Hey Oscar, } \\
\text { Big Bird } \\
\text { brought me } \\
\text { the X. } \\
\text { (Cookie } \\
\text { Monster is } \\
\text { Speaker; } \\
\text { Oscar is } \\
\text { addressee; } \\
\text { movement } \\
\text { from Big } \\
\text { Bird to } \\
\text { Cookie } \\
\text { Monster) }\end{array}$ & $\begin{array}{l}\text { Hey Cookie } \\
\text { Monster, } \\
\text { Oscar } \\
\text { brought } \\
\text { you the X. } \\
\text { (Big Bird is } \\
\text { Speaker; } \\
\text { Cookie } \\
\text { Monster is } \\
\text { addressee; } \\
\text { movement } \\
\text { from Oscar } \\
\text { to Cookie } \\
\text { Monster). }\end{array}$ & $\begin{array}{l}\text { Hey Cookie } \\
\text { Monster, I } \\
\text { brought } \\
\text { Oscar the } \\
\text { X. } \\
\text { (Big Bird is } \\
\text { Speaker; } \\
\text { Cookie } \\
\text { Monster is } \\
\text { addressee; } \\
\text { movement } \\
\text { from Big } \\
\text { Bird to } \\
\text { Oscar) }\end{array}$ & $\begin{array}{l}\text { Hey Big } \\
\text { Bird, you } \\
\text { brought } \\
\text { Cookie } \\
\text { Monster the } \\
\text { X. } \\
\text { (Oscar is } \\
\text { speaker; } \\
\text { Big Bird is } \\
\text { addressee; } \\
\text { movement } \\
\text { from Big } \\
\text { Bird to } \\
\text { Cookie } \\
\text { Monster) }\end{array}$ \\
\hline & $\begin{array}{l}\text { Hey Cookie } \\
\text { Monster, I } \\
\text { brought } \\
\text { the X to } \\
\text { you. } \\
\text { (BB is } \\
\text { Speaker; } \\
\text { CM is } \\
\text { addressee; } \\
\text { movement } \\
\text { from BB to } \\
\text { CM ) }\end{array}$ & $\begin{array}{l}\text { Hey Big } \\
\text { Bird, you } \\
\text { brought the } \\
\mathrm{X} \text { to me. } \\
\text { (Oscar is } \\
\text { speaker; } \\
\text { Big Bird is } \\
\text { addressee; } \\
\text { movement } \\
\text { from Big } \\
\text { Bird to } \\
\text { Oscar) }\end{array}$ & $\begin{array}{l}\text { Hey Cookie } \\
\text { Monster, } \\
\text { Oscar } \\
\text { brought the } \\
\mathrm{X} \text { to me. } \\
\text { (Big Bird is } \\
\text { Speaker; } \\
\text { Cookie } \\
\text { Monster is } \\
\text { addressee; } \\
\text { movement } \\
\text { from Oscar } \\
\text { to Big Bird) }\end{array}$ & $\begin{array}{l}\text { Hey Oscar, } \\
\text { Big Bird } \\
\text { brought } \\
\text { the X to } \\
\text { you. } \\
\text { (Cookie } \\
\text { Monster is } \\
\text { Speaker; } \\
\text { Oscar is } \\
\text { addressee; } \\
\text { movement } \\
\text { from BB to } \\
\text { Oscar) }\end{array}$ & $\begin{array}{l}\text { Hey Big } \\
\text { Bird, I } \\
\text { brought the } \\
\text { X to } \\
\text { Cookie } \\
\text { Monster. } \\
\text { (Oscar is } \\
\text { speaker; } \\
\text { Big Bird is } \\
\text { addressee; } \\
\text { movement } \\
\text { from Oscar } \\
\text { to CM) }\end{array}$ & $\begin{array}{l}\text { Hey Cookie } \\
\text { Monster, } \\
\text { you brought } \\
\text { the X to } \\
\text { Oscar. } \\
\text { (Big Bird is } \\
\text { Speaker; } \\
\text { CM is } \\
\text { addressee; } \\
\text { movement } \\
\text { from CM to } \\
\text { BB }\end{array}$ \\
\hline
\end{tabular}


Table 2.2.c Linguistic Stimuli across the verb go

\begin{tabular}{|c|c|c|c|c|c|c|}
\hline & \multicolumn{6}{|c|}{ Movement from } \\
\hline & $\begin{array}{l}\text { Speaker to } \\
\text { Hearer }\end{array}$ & $\begin{array}{l}\text { Hearer to } \\
\text { Speaker }\end{array}$ & $\begin{array}{l}3^{\text {rd }} \text { person to } \\
\text { speaker }\end{array}$ & $\begin{array}{l}3^{\text {rd }} \text { Person } \\
\text { to } \\
\text { addressee }\end{array}$ & $\begin{array}{l}\text { Speaker to } \\
3^{\text {rd }} \text { person }\end{array}$ & $\begin{array}{l}\text { Hearer to } \\
3^{\text {rd }} \text { Person }\end{array}$ \\
\hline \multirow[t]{2}{*}{ Go } & $\begin{array}{l}\text { Hey } \\
\text { Cookie } \\
\text { Monster, I } \\
\text { went to you } \\
\text { with the X. } \\
\text { (Big Bird is } \\
\text { Speaker; } \\
\text { Cookie } \\
\text { Monster is } \\
\text { addressee; } \\
\text { movement } \\
\text { from Big } \\
\text { Bird to } \\
\text { Cookie } \\
\text { Monster ) }\end{array}$ & $\begin{array}{l}\text { Hey Big } \\
\text { Bird, you } \\
\text { went to me } \\
\text { with the X. } \\
\text { (Oscar is } \\
\text { speaker; } \\
\text { Big Bird is } \\
\text { addressee; } \\
\text { movement } \\
\text { from Big } \\
\text { Bird to } \\
\text { Oscar) }\end{array}$ & $\begin{array}{l}\text { Hey Big } \\
\text { Bird, } \\
\text { Cookie } \\
\text { Monster } \\
\text { went to me } \\
\text { with the X. } \\
\text { (Oscar is } \\
\text { speaker; Big } \\
\text { Bird is } \\
\text { addressee; } \\
\text { movement } \\
\text { from Cookie } \\
\text { Monster to } \\
\text { Oscar) }\end{array}$ & $\begin{array}{l}\text { Hey Cookie } \\
\text { Monster, } \\
\text { Oscar went } \\
\text { to you with } \\
\text { the X. } \\
\text { (Big Bird is } \\
\text { Speaker; } \\
\text { Cookie } \\
\text { Monster is } \\
\text { addressee; } \\
\text { movement } \\
\text { from Oscar } \\
\text { to Cookie } \\
\text { Monster) }\end{array}$ & $\begin{array}{l}\text { Hey Oscar, } \\
\text { I went to } \\
\text { Big Bird } \\
\text { with the X. } \\
\text { (Cookie } \\
\text { Monster is } \\
\text { Speaker; } \\
\text { Oscar is the } \\
\text { addressee; } \\
\text { movement } \\
\text { from } \\
\text { Cookie } \\
\text { Monster to } \\
\text { Big Bird) }\end{array}$ & $\begin{array}{l}\text { Hey Oscar, } \\
\text { you went to } \\
\text { Big Bird } \\
\text { with the X. } \\
\text { (Cookie } \\
\text { Monster is } \\
\text { Speaker; } \\
\text { Oscar is the } \\
\text { addressee; } \\
\text { movement } \\
\text { from Oscar } \\
\text { to Big Bird) }\end{array}$ \\
\hline & $\begin{array}{l}\text { Hey Big } \\
\text { Bird, I } \\
\text { went with } \\
\text { the X to } \\
\text { you. } \\
\text { (Oscar is } \\
\text { speaker; } \\
\text { Big Bird is } \\
\text { addressee; } \\
\text { movement } \\
\text { from Oscar } \\
\text { to Big } \\
\text { Bird) }\end{array}$ & $\begin{array}{l}\text { Hey Cookie } \\
\text { Monster, } \\
\text { you went } \\
\text { with the X } \\
\text { to me. } \\
\text { (Big Bird is } \\
\text { Speaker; } \\
\text { Cookie } \\
\text { Monster is } \\
\text { addressee; } \\
\text { movement } \\
\text { from } \\
\text { Cookie } \\
\text { Monster to } \\
\text { Big Bird) }\end{array}$ & $\begin{array}{l}\text { Hey Oscar, } \\
\text { Big Bird } \\
\text { went with } \\
\text { the X to me. } \\
\text { (Cookie } \\
\text { Monster is } \\
\text { Speaker; } \\
\text { Oscar is the } \\
\text { addressee; } \\
\text { movement } \\
\text { from Big } \\
\text { Bird to } \\
\text { Cookie } \\
\text { Monster) }\end{array}$ & $\begin{array}{l}\text { Hey Big } \\
\text { Bird, } \\
\text { Cookie } \\
\text { Monster } \\
\text { went with } \\
\text { the X to } \\
\text { you. } \\
\text { (Oscar is } \\
\text { speaker; } \\
\text { BB is } \\
\text { addressee; } \\
\text { movement } \\
\text { from CM } \\
\text { to Big Bird }\end{array}$ & $\begin{array}{l}\text { Hey Big } \\
\text { Bird, I went } \\
\text { with the X } \\
\text { to Cookie } \\
\text { Monster. } \\
\text { (Oscar is } \\
\text { speaker; } \\
\text { Big Bird is } \\
\text { addressee; } \\
\text { movement } \\
\text { from Oscar } \\
\text { to Cookie } \\
\text { Monster) }\end{array}$ & $\begin{array}{l}\text { Hey Big } \\
\text { Bird, you } \\
\text { went with } \\
\text { the X to } \\
\text { Cookie } \\
\text { Monster. } \\
\text { (Oscar is } \\
\text { speaker; } \\
\text { Big Bird is } \\
\text { addressee; } \\
\text { movement } \\
\text { from Big } \\
\text { Bird to } \\
\text { Cookie } \\
\text { Monster) }\end{array}$ \\
\hline
\end{tabular}


Table 2.2.d Linguistic Stimuli across the verb take

\begin{tabular}{|c|c|c|c|c|c|c|}
\hline & \multicolumn{6}{|c|}{ Movement from } \\
\hline & $\begin{array}{l}\text { Speaker to } \\
\text { Hearer }\end{array}$ & $\begin{array}{l}\text { Hearer to } \\
\text { Speaker }\end{array}$ & $\begin{array}{l}3^{\text {rd }} \text { person to } \\
\text { speaker }\end{array}$ & $\begin{array}{l}3^{\text {rd }} \text { Person } \\
\text { to } \\
\text { addressee }\end{array}$ & $\begin{array}{l}\text { Speaker to } \\
3^{\text {rd }} \text { person }\end{array}$ & $\begin{array}{l}\text { Hearer to } \\
3^{\text {rd }} \text { Person }\end{array}$ \\
\hline Take & $\begin{array}{l}\text { Hey Oscar, } \\
\text { I took you } \\
\text { the X. } \\
\text { (Cookie } \\
\text { Monster is } \\
\text { Speaker; } \\
\text { Oscar is } \\
\text { addressee; } \\
\text { movement } \\
\text { from } \\
\text { Cookie } \\
\text { Monster to } \\
\text { Oscar) }\end{array}$ & $\begin{array}{l}\text { Hey Cookie } \\
\text { Monster, } \\
\text { you took } \\
\text { me the X. } \\
\text { (Big Bird is } \\
\text { Speaker; } \\
\text { Cookie } \\
\text { Monster is } \\
\text { addressee; } \\
\text { movement } \\
\text { from } \\
\text { Cookie } \\
\text { Monster to } \\
\text { Big Bird) }\end{array}$ & $\begin{array}{l}\text { Hey Oscar, } \\
\text { Big Bird } \\
\text { took me the } \\
\text { X. } \\
\text { (Cookie } \\
\text { Monster is } \\
\text { Speaker; } \\
\text { Oscar is } \\
\text { addressee; } \\
\text { movement } \\
\text { from Big } \\
\text { Bird to } \\
\text { Cookie } \\
\text { Monster) }\end{array}$ & $\begin{array}{l}\text { Hey Cookie } \\
\text { Monster, } \\
\text { Oscar took } \\
\text { you the X. } \\
\text { (Big Bird is } \\
\text { Speaker; } \\
\text { Cookie } \\
\text { Monster is } \\
\text { addressee; } \\
\text { movement } \\
\text { from Oscar } \\
\text { to Cookie } \\
\text { Monster) }\end{array}$ & $\begin{array}{l}\text { Hey Big } \\
\text { Bird, I took } \\
\text { Cookie } \\
\text { Monster the } \\
\text { X. } \\
\text { (Oscar is } \\
\text { speaker; } \\
\text { Big Bird is } \\
\text { addressee; } \\
\text { movement } \\
\text { from Oscar } \\
\text { to Cookie } \\
\text { Monster) }\end{array}$ & $\begin{array}{l}\text { Hey Oscar, } \\
\text { you took } \\
\text { Big Bird } \\
\text { the X. } \\
\text { (Cookie } \\
\text { Monster is } \\
\text { Speaker; } \\
\text { Oscar is } \\
\text { addressee; } \\
\text { movement } \\
\text { from Oscar } \\
\text { to Big Bird) }\end{array}$ \\
\hline & $\begin{array}{l}\text { Hey Cookie } \\
\text { Monster, I } \\
\text { took the X } \\
\text { to you. } \\
\text { (Big Bird is } \\
\text { Speaker; } \\
\text { Cookie } \\
\text { Monster is } \\
\text { addressee; } \\
\text { movement } \\
\text { from Big } \\
\text { Bird to } \\
\text { Cookie } \\
\text { Monster.) }\end{array}$ & $\begin{array}{l}\text { Hey Oscar, } \\
\text { you took } \\
\text { the X to } \\
\text { me. } \\
\text { (Cookie } \\
\text { Monster is } \\
\text { Speaker; } \\
\text { Oscar is } \\
\text { addressee; } \\
\text { movement } \\
\text { from Oscar } \\
\text { to Cookie } \\
\text { Monster. }\end{array}$ & $\begin{array}{l}\text { Hey Cookie } \\
\text { Monster, } \\
\text { Oscar took } \\
\text { the X to me. } \\
\text { (Big Bird is } \\
\text { Speaker; } \\
\text { Cookie } \\
\text { Monster is } \\
\text { addressee; } \\
\text { movement } \\
\text { from Oscar } \\
\text { to Big Bird. }\end{array}$ & $\begin{array}{l}\text { Hey Big } \\
\text { Bird, } \\
\text { Cookie } \\
\text { Monster } \\
\text { took the X } \\
\text { to you. } \\
\text { (Oscar is } \\
\text { speaker; } \\
\text { Big Bird is } \\
\text { addressee; } \\
\text { movement } \\
\text { from } \\
\text { Cookie } \\
\text { Monster to } \\
\text { Big Bird). }\end{array}$ & $\begin{array}{l}\text { Hey Cookie } \\
\text { Monster, I } \\
\text { took the X } \\
\text { to Oscar. } \\
\text { (Big Bird is } \\
\text { Speaker; } \\
\text { Cookie } \\
\text { Monster is } \\
\text { addressee; } \\
\text { movement } \\
\text { from Big } \\
\text { Bird to } \\
\text { Oscar.) }\end{array}$ & $\begin{array}{l}\text { Hey Big } \\
\text { Bird, you } \\
\text { took the X } \\
\text { to Cookie } \\
\text { Monster. } \\
\text { (Oscar is } \\
\text { speaker; } \\
\text { Big Bird is } \\
\text { addressee; } \\
\text { movement } \\
\text { from Big } \\
\text { Bird to } \\
\text { Cookie } \\
\text { Monster). }\end{array}$ \\
\hline
\end{tabular}


Table 2.2.e Linguistic Stimuli across the verb give

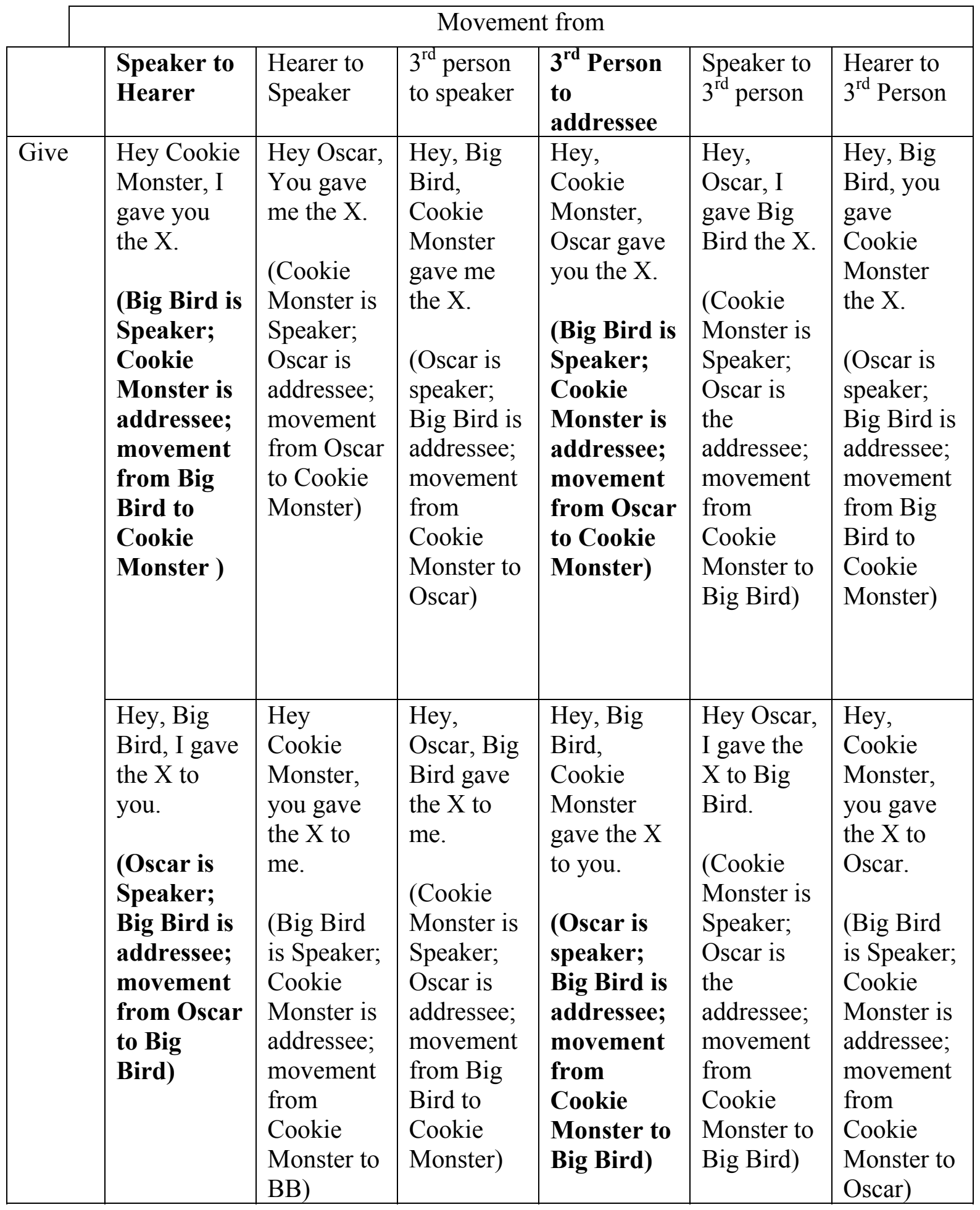


Table 2.2.f Linguistic Stimuli across the verb carry

\begin{tabular}{|c|c|c|c|c|c|c|}
\hline & \multicolumn{6}{|c|}{ Movement from } \\
\hline & $\begin{array}{l}\text { Speaker to } \\
\text { Hearer }\end{array}$ & \begin{tabular}{|l} 
Hearer to \\
Speaker
\end{tabular} & $\begin{array}{l}3^{\text {rd }} \text { person } \\
\text { to speaker }\end{array}$ & \begin{tabular}{|l}
$3^{\text {rd }}$ Person \\
to \\
addressee \\
\end{tabular} & $\begin{array}{l}\text { Speaker to } \\
3^{\text {rd }} \text { person }\end{array}$ & $\begin{array}{l}\text { Hearer to } \\
3^{\text {rd }} \text { Person }\end{array}$ \\
\hline Carry & $\begin{array}{l}\text { Hey Oscar, } \\
\text { I carried the } \\
\mathrm{X} \text { to you. } \\
\text { (Cookie } \\
\text { Monster is } \\
\text { Speaker; } \\
\text { Oscar is } \\
\text { addressee; } \\
\text { movement } \\
\text { from } \\
\text { Cookie } \\
\text { Monster to } \\
\text { Oscar) }\end{array}$ & $\begin{array}{l}\text { Hey Big } \\
\text { Bird, you } \\
\text { carried the } \\
\mathrm{X} \text { to me. } \\
\\
\text { (Oscar is } \\
\text { speaker; } \\
\text { Big Bird is } \\
\text { addressee; } \\
\text { movement } \\
\text { from Big } \\
\text { Bird to } \\
\text { Oscar) }\end{array}$ & $\begin{array}{l}\text { Hey, } \\
\text { Cookie } \\
\text { Monster, } \\
\text { Oscar } \\
\text { carried the } \\
\text { X to me. } \\
\\
\text { (Big Bird } \\
\text { is Speaker; } \\
\text { Cookie } \\
\text { Monster is } \\
\text { addressee; } \\
\text { movement } \\
\text { from } \\
\text { Oscar to } \\
\text { Big Bird) }\end{array}$ & $\begin{array}{l}\text { Hey, Oscar, } \\
\text { Big Bird } \\
\text { carried the } \\
\text { X to you } \\
\text { (Cookie } \\
\text { Monster is } \\
\text { Speaker; } \\
\text { Oscar is } \\
\text { addressee; } \\
\text { movement } \\
\text { from Big } \\
\text { Bird to } \\
\text { Oscar) }\end{array}$ & $\begin{array}{l}\text { Hey, } \\
\text { Cookie } \\
\text { Monster, I } \\
\text { carried the } \\
\text { X to } \\
\text { Oscar. } \\
\text { (Big Bird } \\
\text { is Speaker; } \\
\text { Cookie } \\
\text { Monster is } \\
\text { addressee; } \\
\text { movement } \\
\text { from Big } \\
\text { Bird to } \\
\text { Oscar) }\end{array}$ & $\begin{array}{l}\text { Hey Oscar, } \\
\text { you } \\
\text { carried the } \\
\mathrm{X} \text { to Big } \\
\text { Bird. } \\
\text { (Cookie } \\
\text { Monster is } \\
\text { Speaker; } \\
\text { Oscar is } \\
\text { the } \\
\text { addressee; } \\
\text { movement } \\
\text { from } \\
\text { Oscar to } \\
\text { Big Bird) }\end{array}$ \\
\hline
\end{tabular}

Table 2.2.g Linguistic Stimuli across the verb deliver

\begin{tabular}{|c|c|c|c|c|c|c|}
\hline & \multicolumn{6}{|c|}{ Movement from } \\
\hline & $\begin{array}{l}\text { Speaker to } \\
\text { Hearer }\end{array}$ & $\begin{array}{l}\text { Hearer to } \\
\text { Speaker }\end{array}$ & $\begin{array}{l}3^{\text {rd }} \text { person } \\
\text { to speaker }\end{array}$ & $\begin{array}{l}3^{\text {rd }} \text { Person } \\
\text { to } \\
\text { addressee } \\
\end{array}$ & $\begin{array}{l}\text { Speaker to } \\
3^{\text {rd }} \text { person }\end{array}$ & $\begin{array}{l}\text { Hearer to } \\
3^{\text {rd }} \text { Person }\end{array}$ \\
\hline Deliver & $\begin{array}{l}\text { Hey Oscar, } \\
\text { I delivered } \\
\text { the } \mathrm{X} \text { to } \\
\text { you. } \\
\text { (CM is } \\
\text { Speaker; } \\
\text { Oscar is } \\
\text { addressee; } \\
\text { movement } \\
\text { from CM } \\
\text { to Oscar) }\end{array}$ & $\begin{array}{l}\text { Hey } \\
\text { Cookie } \\
\text { Monster, } \\
\text { you } \\
\text { delivered } \\
\text { the } \mathrm{X} \text { to } \\
\text { me. } \\
\text { (BB is S; } \\
\text { CM is A; } \\
\text { movement } \\
\text { from } \mathrm{CM} \\
\text { to BB) }\end{array}$ & $\begin{array}{l}\text { Hey, Big } \\
\text { Bird, } \\
\text { Cookie } \\
\text { Monster } \\
\text { delivered } \\
\text { the X to } \\
\text { me. } \\
\text { (Oscar is } \\
\text { S; BB is A; } \\
\text { movement } \\
\text { from CM } \\
\text { to Oscar) }\end{array}$ & $\begin{array}{l}\text { Hey, Big } \\
\text { Bird, } \\
\text { Cookie } \\
\text { Monster } \\
\text { delivered } \\
\text { the X to } \\
\text { you. } \\
\text { (Oscar is S; } \\
\text { BB is A; } \\
\text { movement } \\
\text { from CM } \\
\text { to BB) }\end{array}$ & $\begin{array}{l}\text { Hey, } \\
\text { Oscar, I } \\
\text { delivered } \\
\text { the } \mathrm{X} \text { to } \\
\text { Big Bird. } \\
\text { (CM is S; } \\
\text { Oscar is } \\
\text { the A; } \\
\text { movement } \\
\text { from CM } \\
\text { to BB) }\end{array}$ & $\begin{array}{l}\text { Hey, } \\
\text { Oscar, you } \\
\text { delivered } \\
\text { the } \mathrm{X} \text { to } \\
\text { Big Bird. } \\
\text { (CM is S; } \\
\text { Oscar is } \\
\text { the A; } \\
\text { movement } \\
\text { from Oscar } \\
\text { to BB) }\end{array}$ \\
\hline
\end{tabular}




\section{$\underline{2.3 \text { Nonlinguistic Stimuli }}$}

Nonlinguistic stimuli consisted of video clips depicting motion events with an object between three live costumed actors accompanied by a dubbed narration of the motion event. The three actors were seated in a triangular configuration where one actor was facing directly toward the camera, while the other two were facing each other, each slightly turned toward the camera in order for the frontal facial plane to be perceivable. This seating arrangement remained constant throughout all trials, with the roles of the actors changing instead of their positioning. The chairs were placed at a maximal distance of about eight feet equidistant from one another, as dictated by the width of the camera angle. Figure 2.3.a below depicts the blocking described above.

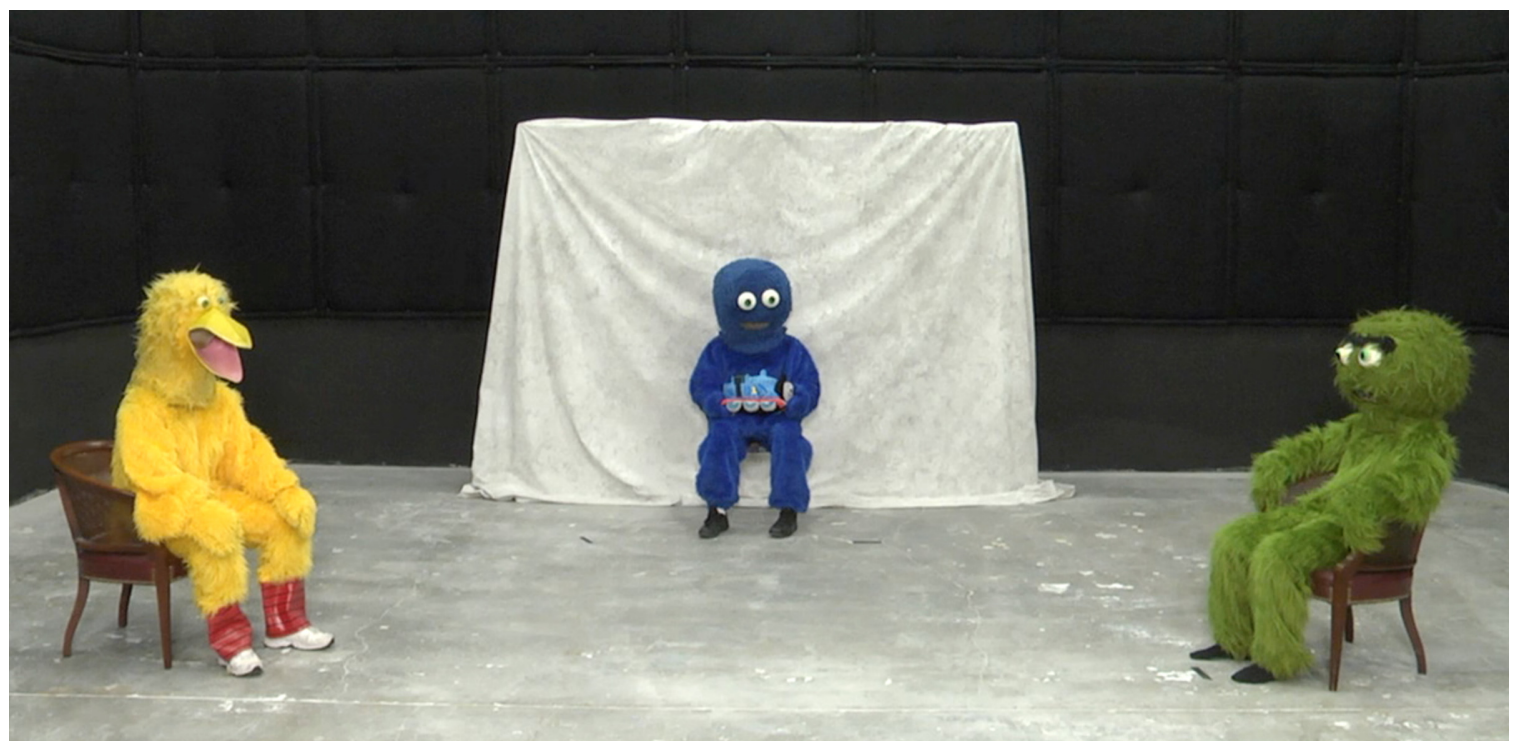

Figure 2.3.a Blocking of Actors/Set in Nonlinguistic Stimuli Videos

Each trial began with the actors seated and the speaker capturing the addressee's attention by saying either "Hey (addressee), look!” or "Hey, (addressee), what's that?"; the latter was used when the addressee was the actor performing the movement, as it 
would be pragmatically infelicitous to tell one to look at her/himself in this scenario. In each case, the actor performing the movement was in possession of an item. After the speaker directed the addressee's attention to the item holder, the actor with the item would deliver this item to another actor and return to her/his seat in a backtracking movement (without turning away from the recipient). Once the mover was seated, the speaker would then turn to the addressee and say "Hey, (addressee), (mover) (verb [+past tense] (preposition)(recipient/ patient ) (preposition)(patient/ recipient), e.g. "Hey, Oscar, Big Bird came to you with the ball'. All narrations were recorded in a sound booth and later time-matched to their respective video recordings; this was done to circumvent the previously unforeseen problematic sound wave modulation resulting in overly muffled speech caused by the architecture of the headpieces worn by the actors.

\section{$\underline{2.4 \text { Participants }}$}

Forty-five participants belonging to one of three fifteen-member groups were tested: English monolinguals, early Spanish-English bilinguals and later Spanish-English bilinguals. All bilinguals shared Spanish as a first language. For this study, participants were considered early bilinguals if they had acquired English at or before the age of four; later bilinguals acquired English at or after the age of five. All testing was performed in Miami, Florida. Seven of the fifteen monolinguals were raised outside of Miami but at the time of testing had spent at least two concurrent years residing in Miami. The other eight monolinguals were born and raised in Miami and had spent no more than four years living outside of Miami, also having spent the last two concurrent years in residence in Miami. This group consisted of eight males and seven females with a mean age of 32.6 
years and median age of 28.5 years. Mean length of residence in Miami for this group was 20.6 years with a median of 24 years. The early bilingual group included thirteen females and two males with a mean age of 26.5 years and a median age of 25.5. Average age of acquisition (AoA) of English for this group was 2.2 years with a median AoA of 3 years. Mean length of residence in Miami for this group was 22.5 years with a median of 22 years. Twelve participants indicated Cuban heritage, one Honduran heritage, one Puerto Rican heritage and one Peruvian and Uruguayan heritage. The later bilingual group included ten females and five males with a mean age of 38.3 years and a median age of 27.8. Average age of acquisition (AoA) of English for this group was 7.7 years with a median AoA of 7 years. Mean length of residence in Miami for this group was 27.5 years with a median of 26 years. For this group, eight participants indicated Cuban heritage, three Colombian heritage, two Venezuelan heritage one Honduran heritage and one Salvadorian heritage. All bilinguals reported no or very minimal knowledge of any other language besides English and Spanish. All participants were administered the Peabody Picture Vocabulary Test or PPVTTM_4 (Dunn, L. [Lloyd] \& Dunn, D., 2007) and the bilinguals were also tested with the Spanish version of the same exam, the Test de Vocabulario en Imágenes Peabody or TVIPTM (Dunn, L. [Lloyd], Lugo, D., Padilla, E. \& Dunn, L. [Leota], 1989); all subjects scored within the normal proficiency range for their respective languages.

\subsection{Procedure}

Testing was administered in a comfortable, quiet space convenient to the participant. After consenting to participate in the study, participants were asked to fill out 
extensive questionnaires regarding demographic information and language use (see Appendices A and B).

The researcher then directed the participants towards a 13" Apple MacBook Pro laptop, which served as the medium for the experiment. The stimulus presentation software Superlab 5.0 by Cedrus was used to present the video stimuli and to record the participants' responses. A Bluetooth-enabled Apple Magic Trackpad with Mobee Magic Numpad 2.2 software was used as a keypad as a more ergonomic hand-placement alternative to the number keys built-in below the laptop screen. Headphones were provided to ensure that the stimuli were sufficiently audible. An on-screen prompt in font type Lucida Grande, font size 24 was provided as follows:

Sesame Street is making videos to teach children in other countries English. They want opinions from speakers of English about whether what the characters say sound okay given what happened in the video. What Sesame Street wants to know is whether competent English speakers would say things this way.

$$
\begin{aligned}
& \text { 1= You absolutely should not say it like that. } \\
& 2=\text { I don't think you should say it like that. } \\
& 3=\text { I'm really not sure. } \\
& 4=\text { I think that sounds fine. } \\
& 5=\text { It's absolutely fine. }
\end{aligned}
$$

The following three videos will be for practice.

Once a video has been played, it cannot be played again.

Please press the spacebar to begin.

The videos were programmed to advance automatically after an input keystroke from 1 to 5, corresponding to the scores on the Likert scale provided in the instructions; 
the Likert scale remained visible below the video onscreen throughout the trials for the participants' ease of reference. Three practice videos were shown in order to acclimate participants to the testing procedure. After the practice trials, the target items were presented. All experimental clips (both target and non-target) were presented in a randomized order determined by Superlab 5.0. for each participant. 
Chapter 3: Results

\section{$\underline{3.1 \text { Hypotheses }}$}

It was hypothesized that early bilinguals should perform better i.e. in a fashion patterning more closely with English monolingual performance than the later acquiring bilinguals in the conditions of movement to an addressee, corresponding to the conditions where English and Spanish diverge in terms of the patterning of come/bring and go/take. It was also hypothesized that English monolinguals' performance be commensurate with the previously attested patterns for English in the literature. No explicit predictions are made for the effect, if any, on the positioning of the indirect and patient $\mathrm{s}$ on ratings by any language group.

\section{$\underline{3.2 \text { Analyses }}$}

\section{$\underline{3.2 .1 \text { Analyses of Variance with all variables }}$}

Repeated measures analyses of variance were conducted using language group, comprised of monolingual English speakers, early sequential bilinguals and later sequential bilinguals, as the between-subjects variable. Motion to whom (toward the speaker, the addressee or the third party), deictic direction (come/bring as opposed to go/take), causativity (come and go as non-causatives patterning differently from bring and take as causatives) and object position (the recipient in first position after the verb or in second position in the linguistic stimuli) served as the within-subjects variables. Scores for the "who was moving" variable were merged in order to be able to perform the appropriate analyses and thus the minimum score for any given condition was 2 and the maximum was 10 (each constituent score was from 1 to 5). 


\subsubsection{Main Effects}

The analyses showed main effects of Motion to Whom, $F(2,84)=41.60, p<.000$, Deixis, $\mathrm{F}(1,42)=110.17, \mathrm{p}<.000$, Causitivity, $\mathrm{F}(1,42)=179.12, \mathrm{p}<.000$, in addition to a near-significant main effect of Object position, $F(1,42)=3.191, p=.081$. The significant effect of Motion To Whom was due to the fact that acceptance of utterances in cases of motion towards the speaker was generally lower (5.45 on a scale of 1 to 10$)$ than acceptance of utterances when motion was to the addressee (6.48) or the third party (6.46), $p=.001$. The effect of Deixis was due to higher acceptance rates with come/bring (6.79) than with go/take (5.47). The effect of Causativity reflects the fact that there was higher acceptance of bring/take (7.41) than of come/go (4.84). The near-significant effect of object position was due to higher acceptance rates for the recipient in first (6.22) as opposed to second position in the utterance (6.04) (I went to Big Bird with the ball).

\section{$\underline{3.2 .3 \text { Interaction Effects }}$}

These main effects were modified by two- and three-way interactions. One group involved To Whom, Deixis, Causativity, and Language: Significant interactions occurred between To Whom $x$ Language group, $F(4,84)=4.64, p=.002$, To Whom $x$ Deixis, $\mathrm{F}(2,84)=108.43, \mathrm{p}<.000$, To Whom $\mathrm{x}$ Causativity, $\mathrm{F}(2,84)=13.63, \mathrm{p}<.000$, Deixis $\mathrm{x}$ Causativity, $\mathrm{F}(1,42)=90.87, \mathrm{p}<.000$, To Whom $\mathrm{x}$ Deixis $\mathrm{x}$ Causativity, $\mathrm{F}(2,84)=4.61$, $\mathrm{p}=.013$, and a near-significant interaction of To Whom $\mathrm{x}$ Deixis $\mathrm{x}$ Causitivity $\mathrm{x}$ Language group, $\mathrm{F}(4.84), \mathrm{p}=.072$.

A second group involved To Whom, Deixis, Object position, and Language: Significant interactions occurred for Deixis x Object position, $F(1,42)=52.05$, $p<.000$ 
and, To Whom $x$ Deixis $x$ Object position $F(2,84)=4.71, p=.011$, Deixis $x$ Object position $\mathrm{x}$ Language group $(\mathrm{F}(2,42)=3.78, \mathrm{p}=.031$. A near-significant interaction occurred for To Whom $\mathrm{x}$ Deixis $\mathrm{x}$ Object position $\mathrm{x}$ Language group, $\mathrm{F}(4,84)=2.12, \mathrm{p}=.086$.

A third group involved Causativity, Object position, and Language: Causitivity x Object position, $\mathrm{F}(1,42)=42.22, \mathrm{p}<.000$, Deixis $\mathrm{x}$ Causitivity $x$ Object position $\mathrm{F}(1,42)=8.49, \mathrm{p}=$ .006 , and Causitivity x Object position $x$ Language group, $F(2,42)=4.39, \mathrm{p}=.019$.

\subsubsection{Follow-up Analyses by Motion to Whom}

In order to more deeply understand these interactions, follow up analyses of variance were conducted for each of the To Whom conditions: to speaker, to addressee and to a third party.

\subsubsection{Follow-up Analyses by Motion to Whom - Motion to a Speaker}

Performance for Motion Toward Speaker across all verbs and object positions is shown in Figure 3.1

For motion to a speaker, main effects of Deixis, $F(1,42)=272.91, p<.000$, Causitivity, $F(1,42)=107.23, p<.000$, and Object position, $F(1,42)=4.21$, $p=.046$ were observed. The main effect of deixis was due to a higher acceptance (7.37) of come/bring over go/take (3.52). This result is in line with the hypothesis for motion toward a speaker, as come/bring are the felicitous verbs for this condition in both English and Spanish. The main effect of causativity was due to a higher acceptance of bring/take (6.4) over come/go (4.47). In contrast to the effect of deixis, the preference for bring/take was unexpected, as the causative counterparts were more accepted than the non-causatives. 
The main effect of object position resulted from a preference for the ordering of recipient before patient (5.58), as opposed to the patient before the recipient (5.31). Two-way interactions were also found between Deixis $x$ Causitivity, $F(1,42)=79.87, p<.000$, Deixis $\mathrm{x}$ Object position, $\mathrm{F}(1,42)=78.46, \mathrm{p}<.000$ and Causitivity $\mathrm{x}$ Object position, $\mathrm{F}(1,42)=12.81, \mathrm{p}=.001$. These interactions are explored below by examining performance by individual verb.

\subsubsection{Follow-up Analyses by Motion to Whom - Motion to a Speaker by Verb Type}

Follow-up analyses examining performance with each verb separately revealed that for come, bring and take, but not go, main effects of Object position were found, $F(1,42)=39.44, p<.000, F(1,42)=11.12, p=.002$, and $F(1,42)=18.52, p<.000$, respectively. For come, participants scored the recipient first ordering as more acceptable (6.49) than the recipient second (4.89). The same preference was shown for bring, with a mean score of 9.51 for the recipient first as compared to second (8.6). The opposite preference was found for take, where the preferred order was the recipient second (4.44) to the recipient first (3.13). A two-way interaction was observed for go between Object position $\mathrm{x}$ Language group, $F(2,42)=3.58, p=.037$. Follow up analyses show that there was no difference between groups when the recipient was first with go and when the recipient came second, but there was a near-significant effect of language group $\mathrm{F}(2,42)=2.18$, $\mathrm{p}=.126$. Pairwise comparisons show that the difference lies in acceptance between the early bilinguals and the later bilinguals with a difference of $p=.044$, with the late bilinguals less accepting of the latter construction. 
Figure 3.1: Mean Scores of Verb x Object Position x Language Group to the Speaker

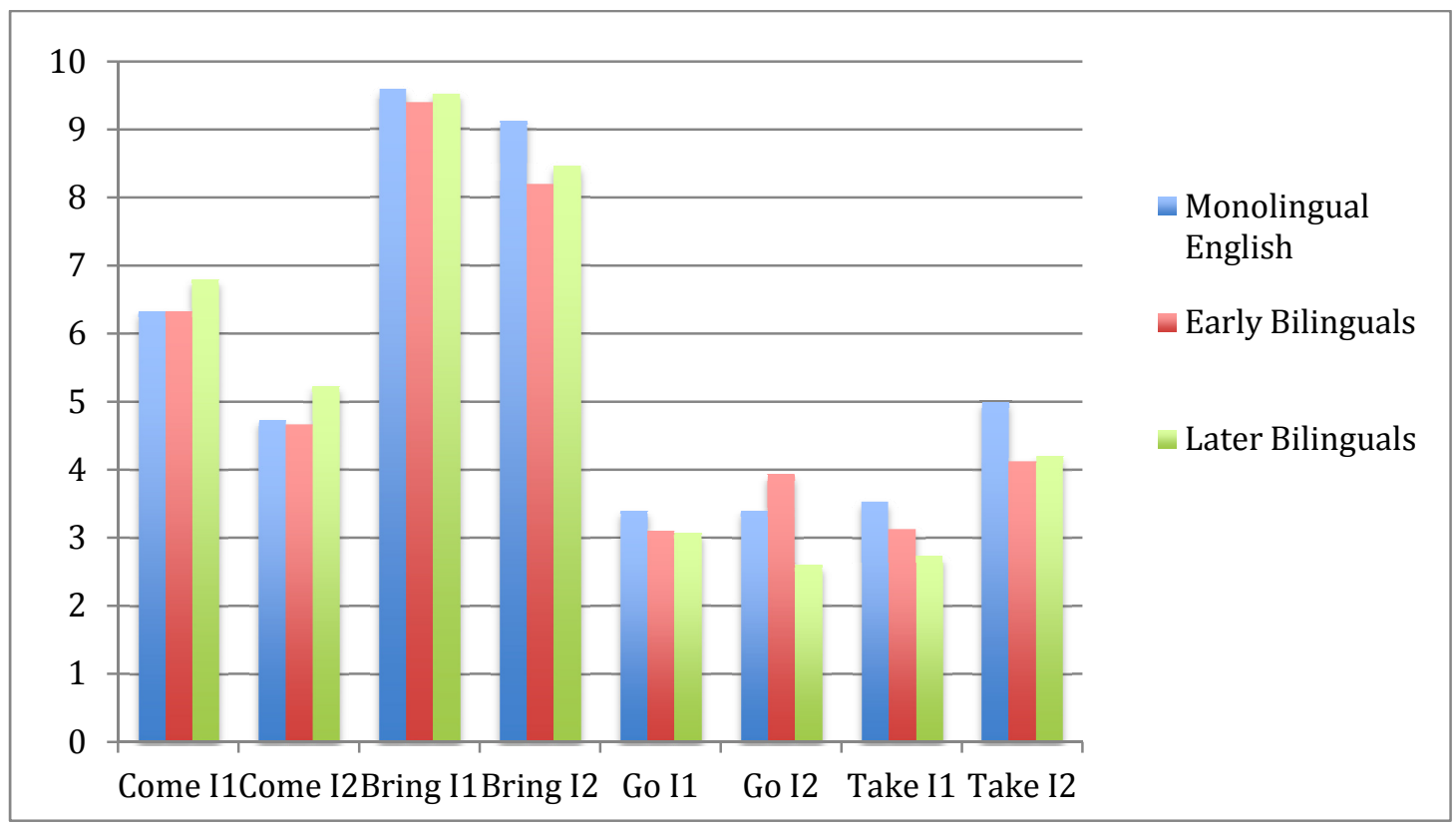

\subsubsection{Follow-up Analyses by Motion to Whom - Motion to an Addressee}

Performance for Motion to an Addressee across all verbs and object positions is shown in Figure 3.2

For motion toward an addressee, main effects of Deixis, $\mathrm{F}(1,42)=32.59, \mathrm{p}<.000$ and Causitivity, $\mathrm{F}(1,42)=126.97, \mathrm{p}<.000$ were shown. The main effect of Deixis was caused by a higher rating of acceptability for come/bring (7.04) than for go/take (5.92). This finding coincides with the expected performance for motion to an addressee for English. It was predicted that if differences did in fact emerge between the bilinguals and the monolinguals, it would be in this condition, as this is where the languages pattern differently; no such effect was found between the language groups. For Causativity, bring/take were more strongly preferred (7.85) than come/go (5.11) for this condition. As for motion to the speaker, this preference for the causative was unexpected. In addition, 
two-way interactions between Deixis x Causitivity, $F(1,42)=26.04, p<.000$, Deixis $x$ Object position, $\mathrm{F}(1,42)=9.66, \mathrm{p}=.003$ and Causitivity x Object position, $\mathrm{F}(1,42)=18.69$, $\mathrm{p}<.000$ were found. A near-significant three-way interaction was also found between Deixis $x$ Object position $x$ Language group, $F(2,42)=3.19, p=.051$. To further explore these interactions, analyses were performed for each verb separately.

\subsubsection{Follow-up Analyses by Motion to Whom - Motion to an Addressee by Verb Type}

Follow-up analyses examining performance with each verb revealed that for motion toward an addressee, main effects of Object position were observed for come $\mathrm{F}(1,42)=18.42, \mathrm{p}<.000$, go, $\mathrm{F}(1,42)=6.76, \mathrm{p}=.013$, and take, $\mathrm{F}(1,42)=13.26, \mathrm{p}=.001$, but not for bring. In the case of come, participants preferred the recipient first (5.91) to the recipient second (4.56) as was also the case for go, (5.36 to 4.60). In the case of take, the opposite preference was shown with recipient second judged as more acceptable (7.44) to the patient-first (6.27). 
Figure 3.2: Mean Scores of Verb x Object Position x Language Group to the Addressee

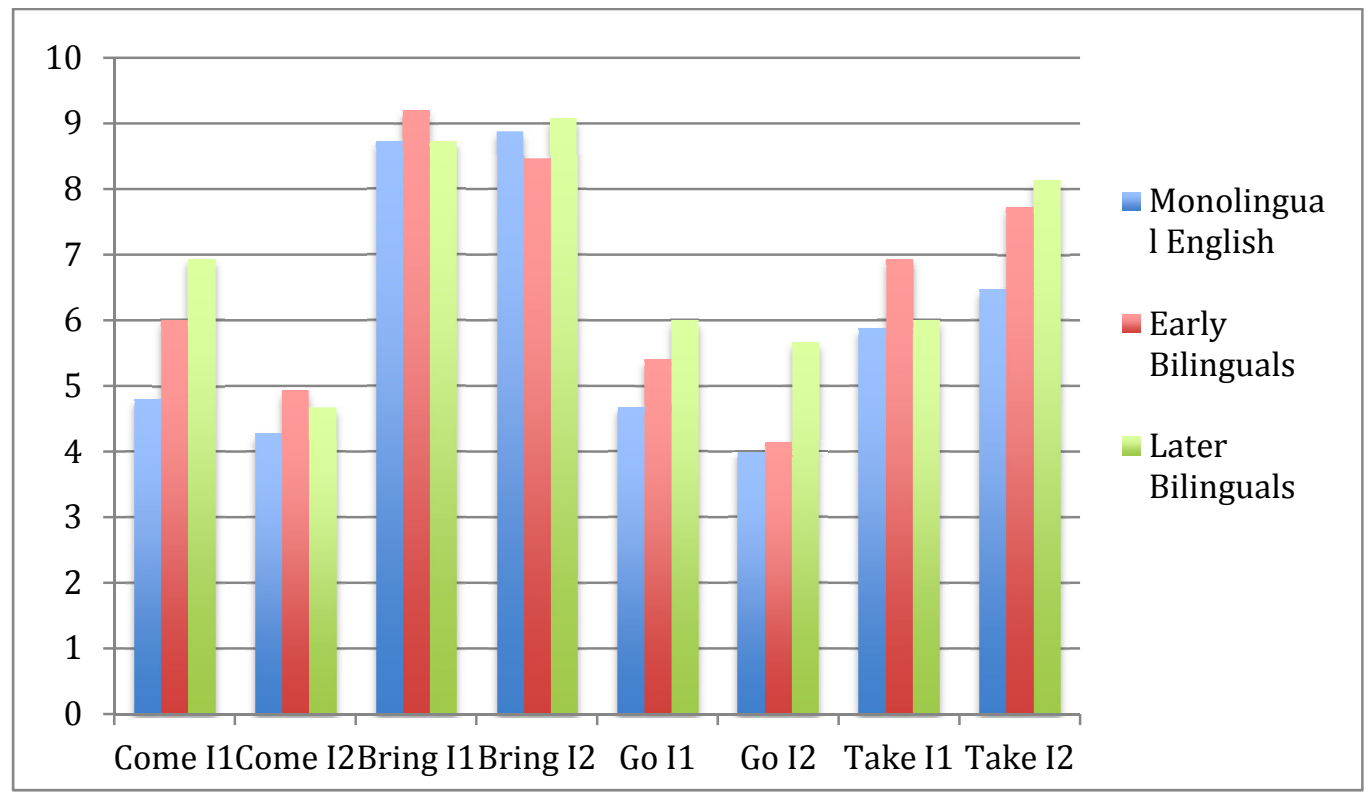

\subsubsection{Follow-up Analyses by Motion to Whom - Motion to a Third Party}

Performance for Motion to a Third Party across all verbs and object positions is shown in Figure 3.2

For motion to a third party, main effects of Deixis, $\mathrm{F}(1,42)=16.22, \mathrm{p}<.000$ and Causitivity, $\mathrm{F}(1,42)=150.10, \mathrm{p}<.000$ were found. The main effect of Deixis was precipitated by a preference for go/take (6.97) over come/bring (5.94) in this condition. This result was anticipated for movement to a third party in English, as well as in Spanish, where go and take are felicitous. For Causitivity, bring/take were deemed more acceptable (7.96) than come/go (4.95). This preference for the causative members of the verb pairings was previously unpredicted. Two-way interactions between Deixis x Causitivity, $F(1,42)=22.10, p<.000$, Deixis $x$ Object position, $F(1,42)=17.25, p<.000$ and 
Causitivity x Object position, $\mathrm{F}(1,42)=36.36, \mathrm{p}<.000$ emerged. A near-significant twoway interaction occurred between Causitivity $x$ Language group, $F(1,42)=2.52$, $p=.093$. Three-way interactions were observed between Deixis x Object position $\mathrm{x}$ Language group, $\mathrm{F}(2,42)=3.86, \mathrm{p}=.029$ and Deixis $\mathrm{x}$ Causitivity $\mathrm{x}$ Object position, $\mathrm{F}(1,42)=6.01$, $\mathrm{p}=.018$, with a near-significant interaction between Deixis $\mathrm{x}$ Causitivity $\mathrm{x}$ Language group, $\mathrm{F}(2,42)=2.80, \mathrm{p}=.072$. In order to gain a clearer understanding of these results, additional analyses were performed for each verb individually.

3.2.10 Follow-up Analyses by Motion to Whom - Motion to a Third Party by Verb Type In the case of motion toward a third party, main effects of object position were found for come, $\mathrm{F}(1,42)=18.42, \mathrm{p}<.000$ and take, $\mathrm{F}(1,42)=35.43, \mathrm{p}<.000$, with a nearsignificant effect for $g o, \mathrm{~F}(1,42)=2.68, \mathrm{p}=.109$. For come, the recipient first was preferred (4.62) to the recipient second (3.44). In the case of take, the recipient second was in fact preferred (8.93) over the recipient first (7.20). A two-way interaction was observed between Object position $\mathrm{x}$ Language group for come, $\mathrm{F}(2,42)=3.56, \mathrm{p}=.037$ and for take $\mathrm{F}(2.42)=6.10, \mathrm{p}=.005$. Follow up analyses indicated no significant differences with come, but with take with the recipient first, there was a significant difference across the groups $\mathrm{F}(2,42)=3.30, \mathrm{p}=.046$. Pairwise comparisons show the difference was between early and later bilinguals, $\mathrm{p}=.016$. In addition, although not significant, monolinguals differed from later bilinguals, at $\mathrm{p}=.096$. Later bilinguals were less accepting of this construction, e.g. "Hey, Big Bird, you took Oscar the ball", than the other language groups. 
Figure 3.3: Mean Scores of Verb x Object Position x Language Group to the Third Party

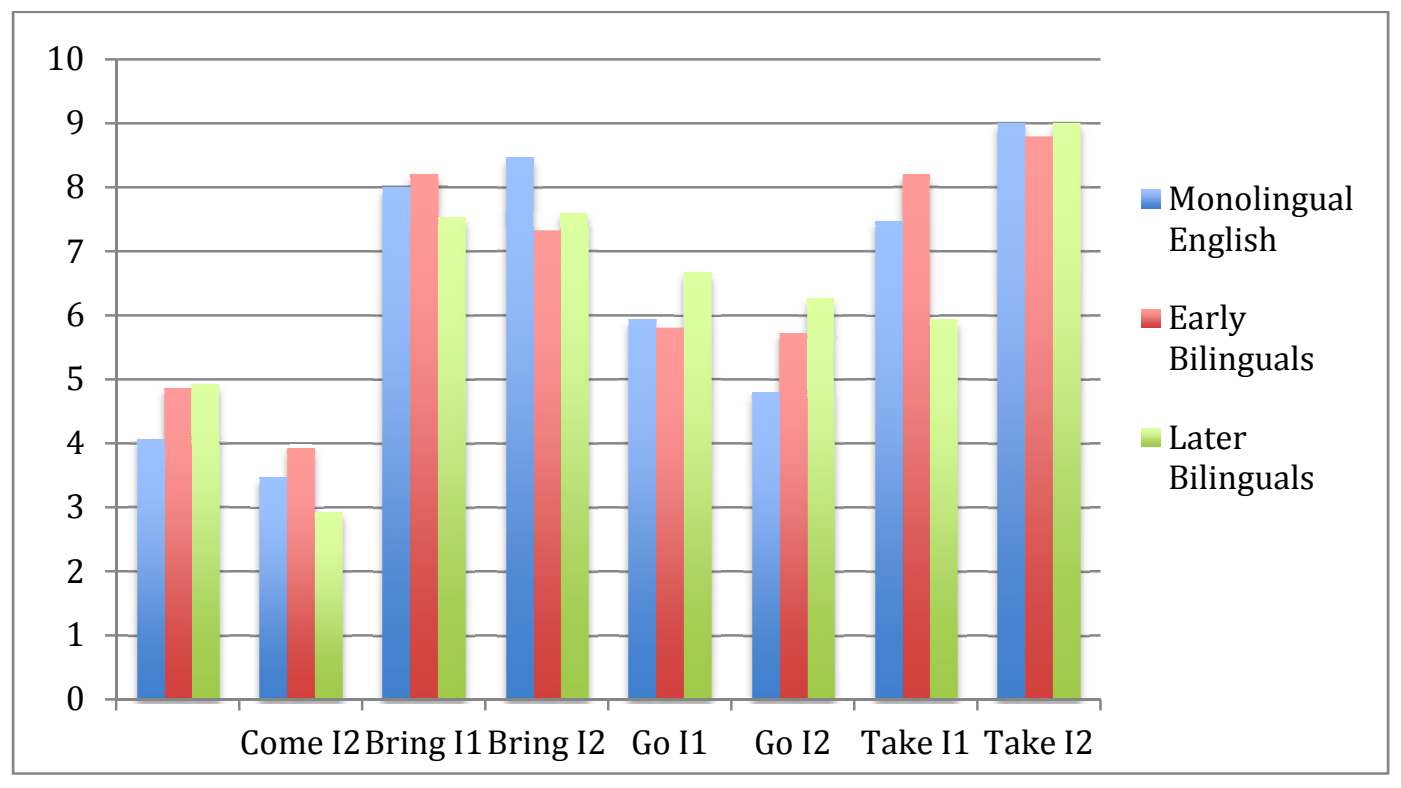




\section{Chapter 4. Discussion}

The findings of this investigation reveal interesting similarities and somewhat unanticipated facts about the acceptance of deictic verb usage among English monolinguals and early and later acquiring Spanish-English bilinguals in Miami. On the whole, the monolinguals and bilinguals patterned quite closely in their performance across the different verbs and motion conditions.

For all participants and motion goals, bring was most preferred, followed by take, come and go being the least preferred generally. It is worthwhile to explore why this might be the case. The difference between judgments of verbs of the same deictic direction, come patterning with bring and go with take, with the only difference between them being causativity, is surprising. As bring and take are merely the causative results of come and go, respectively, there is no obvious theoretical reason why bring should be so strongly preferred over come, even in conditions where come and bring are felicitous, as in motion toward a speaker. One possible explanation for this finding is that come and go are being treated as intransitive verbs in that participants are much less likely to accept the use of these verbs with accompanying oblique objects (...came/went with the ball) whereas bring and take are evidently being privileged to take patient $\mathrm{s}$ as a complement. As such, "Big Bird brought the ball to you" is preferred over "Big Bird came with the ball to you". The treatment of bring deserves further consideration. Bring continued to be very highly rated across the language groups, with scores similar to and ,in some cases, higher than those of take, even in conditions that would predict its infelicity. Due to this fact, it may very well be a possibility that there is an innovative process underway for this 
verb. Speakers of English may be dissociating the traditional deictic element from bring and instead using it in a non-deictic fashion as a verb that simply signifies conveyance from one point to another. Upon further review of the literature regarding bring, this nondeictic usage has been presented through anecdotal evidence by Hockett (1990) as an "intrusive" use of bring for take and as a general verb for conveyance in all cases. Although innovation may offer a viable explanation for these findings, a possible alternative is that existing linguistic analyses of bring are incomplete; current analyses may fail to accurately present the manifold concepts encompassed under the verb.

In terms of performance on the different motion paths (to a speaker, to an addressee and to a third party), all groups conformed to the attested patterns for English. That is to say that for motion to the speaker and motion to the addressee, monolinguals and both groups of bilinguals preferred the use of come and bring as opposed to go and take. It is especially important to highlight that for Spanish, the use of go and take (not come and bring) would be felicitous with motion towards an addressee; this result demonstrates that when speaking English, (even later) bilinguals are able to successfully select the appropriate deictic parameters for the discursive context. For motion to a third party, all groups rated go and take as appropriate as predicted by both the English and Spanish deictic systems. Again, it should be noted that in some instances, bring received scores equal to or higher than either go or take. Similar performance between the monolinguals and bilinguals continued for preference of object position across the verbs, with a few exceptions, discussed below.

For the verb come, all participants preferred constructs where the recipient preceded the patient, e.g. "Oscar, Big Bird came to you with the ball” vs. "Oscar, Big 
Bird came with the ball to you". Across bring, participants favored both constructions about equally in motion toward the addressee and to a third party. For motion to a speaker, there was marked preference for the recipient first, as seen above with come "Oscar, Big Bird brought me the ball". In the case of take, the recipient second was preferred overall as in "Big Bird, you took the ball to Cookie Monster" vs. "Big Bird, you took Cookie Monster the ball" for motion to a speaker and a third party. The result for the latter motion path was due to the later bilinguals' relative rejection of the recipient first. It is posited that this may be due to the requirement of a full noun phrase in this construction; the relevance of this fact vis á vis Spanish symmetry is elaborated later. For motion to an addressee, the opposite was the case, where the recipient first was favored, as in "Oscar, Big Bird took you the ball". Lastly, for go, for motion to a speaker, both orders are about equally disfavored by all except for a pronounced disapproval of recipient second by later bilinguals, as exemplified by "Big Bird, you went with the ball to me". For motion to an addressee and to a third party, all generally preferred the recipient first order. Predictions about the preferred object position across groups were not previously proposed. Nonetheless, the source(s) of these object position preferences can be speculated upon. As previously alluded to, this may be a result of come and go functioning as intransitive verbs within the speakers' grammar, thus blocking the use of the patient as a complement and facilitating the use of the oblique object construction. In contrast to a purely syntactically grounded explanation of this phenomenon, frequency of the construct in the input could also explain why certain verbs tend to collocate with particular object position orders; this account ultimately fails to explain exactly why one 
order would be preferred over another in a given context but acknowledges that there may be explanations that are not direct results of a syntactic prohibitions.

In general, where there were differences across the language groups, it appeared to be due to an effect of object position. This finding was unanticipated and possible explanations are explored below. A question that emerges from these results is why the later bilinguals seem to be more conservative in their scoring of certain orderings across object positions more than the earlier bilinguals. A bilingual advantage in metalinguistic awareness and executive function has repeatedly been found across different language pairings and varied tasks. These heightened skills in executive function encompass the ability to dissociate the linguistic form from the semantic content of an utterance, selectively attend to pertinent information, relay between tasks with differing demands and inhibit attention to distracting or irrelevant information (Bialystok 1993, 1999, 2001a, 2001b; Bialystok and Ryan 1985; Bialystok et al. 2004; Hernandez Pardo, Costa and Sebastián-Gallés 2008; Johnson 1991).With this knowledge, one may expect that later bilinguals would be better able than monolinguals to selectively attend to the relevant information (the deictic verb) and inhibit those aspects of the stimuli that had no effect on the felicity of the verb given the movement path (object position). In line with the literature, it would be anticipated that bilinguals would perform the same as monolinguals but this result was not borne out by the data. It may be the case that later bilinguals are attending not only to the deictic verb itself (again, their performance on this element is equal to that of the other groups) but also to the ordering of the object position: it is here that they are showing a marked preference in some cases. What could precipitate this effect in this group? A potential cause may be that certain object positions 
are strongly privileged in Spanish and these preferences are being carried over to English for equivalent structures in translation.

An example of a construct judged much lower by the later bilinguals was from motion to a third party across the verb come with the recipient second (see Figure 4.3): all groups rated this condition low as it is infelicitous in English. Here, early bilinguals again tended to be more permissive than monolinguals but not significantly different. In contrast, later bilinguals were significantly lower than their bilingual counterparts. This may partially be explained by analyzing the translation equivalents from Spanish. In Spanish, it is more natural in this condition to say Tu viniste a Big Bird con la pelota 'you came to Big Bird with the ball' than to say Tu viniste con la pelota a Big Bird (viniste being semantically infelicitous for motion to a third party). In Spanish, the felicitous verb with the recipient first construct would be Fuiste a Big Bird con la pelota 'you went to Big Bird with the ball', with $a$ serving as the preposition 'to'. It is plausible that later bilinguals judged the entire construct "You went to Big Bird with the ball" as low because the former lacks the overt preposition — an element that is obligatory in Spanish. For motion toward the speaker with the verb go (see Figure 4.1), the findings are similar. Here, there is a significant interaction between object position and language group, with later bilinguals demonstrating a greater preference for the recipient first construct than the earlier bilinguals. Here, the preferred construct 'Fuiste a mi con la pelota' (where fuiste is infelicitous) has the translational equivalent 'You went to me with the ball'; the nonpreferred construct is 'Fuiste con la pelota a mi' whose translational equivalent is 'You went with the ball to me'. In either case, the constituents remain ordered in the same way in both English and Spanish. It is important to note that with the felicitous verb for this 
movement condition, came, the preferred structure for both languages would most likely be that of the recipient first, aligning with the demonstrated responses. This line of reasoning becomes more compelling with the evidence from the verb take with motion to a third party (See Figure 4.3). For this condition, take is felicitous for both Spanish and English; as such, there should be no interference caused by infelicity in one or both languages, as was the case above. In Spanish, it is less natural in this condition to say $T u$ llevaste a Big Bird la pelota 'you took [to] Big Bird the ball' than to say Tu llevaste la pelota a Big Bird 'you took the ball to Big Bird'. Again here, the construct with the recipient first requires the preposition and its translational equivalent 'You took Big Bird the ball' lacks this, whereas the order with the recipient second preserves the exact constituents and ordering of these as in Spanish. In any case, only later bilinguals showed this effect of object position; this fact has no practical ramifications for these English speakers other than a possible attenuation of optionality in object position usage as compared to monolinguals.

The results of this study provide experimental answers to previously unstudied questions about how Spanish-English bilinguals in a highly bilingual context such as Miami navigate aspects of spatial deixis, namely verbs of motion, in English. As a general trend, bilinguals accept deictic verbs of motion usage much the same way that monolinguals do across all motion paths and deictic verbs. In cases where differences do emerge, this is shown to be a result of object position preference and not of a divergence from the English deictic system per se. Based on these findings, it can be concluded that monolingual-like acquisition of English deictic verbs of motion is in fact possible even in a linguistic setting where Spanish is so pervasive. Although there is significant access to 
Spanish and non-native Spanish-influenced English in Miami, the results of this study show little support for interference from Spanish on the semantics of deictic verbs of motion in English.

\section{$\underline{4.1 \text { Future Directions }}$}

As evidenced by the study elaborated above, acceptance of deictic verbs of motion is a very complex psycholinguistic construct that is simultaneously influenced by a multitude of linguistic and metalinguistic factors. In order to continue the thorough investigation of deictic verbs of motion usage by Spanish-English bilinguals, a series of follow up studies is proposed. Due to the fact that later bilinguals made more conservative judgments in unpredicted conditions, it would be of value to investigate the effect of transitivity. In order to accomplish this goal, a procedure very similar to the above could be constructed where later bilinguals would be presented with aural or visual (reading) stimuli of differing transitivity. For example, utterances of the type "You took to BB the ball" could be presented along with the intransitive counterpart, i.e. "You took BB the ball", and participants could be asked to judge which construction they most prefer. Another interesting possibility would be to modify the above study so that it functioned as a productive task instead of a receptive one, as it is currently. The above study sheds much needed light on to how bilinguals and monolinguals accept deictic motion usage in a well-delineated communicative context but it is unable to address how these populations actually use deictic verbs of motion in their own production. It could very well be the case that productive usage and receptive acceptance of others' usage of these constructions are only loosely related or possibly intimately intertwined. Another 
avenue of investigation currently underway is to test the same conditions of this study paradigm in Spanish in an attempt to explore how bilinguals are accepting deictic motion verbs within the parameters set by Spanish. A very interesting opportunity to examine executive functioning in bilinguals would be to have mixed trials between Spanish and English in the same testing procedure to see if bilinguals are able to effectively toggle between their two language while still accepting or producing deictic verbs as dictated by the attested patterns of the respective languages. 


\section{Works Cited}

Bialystok, E. (1993). Metalinguistic awareness: The development of children's representations of language. In Systems of representation in children:

Development and use, ed. C. Pratt and A.Garton, 211-33. London: Wiley.

Bialystok, E. (1999). Cognitive complexity and attentional control in the bilingual mind. Child Development 70, 5, 636-644.

Bialystok, E. (2001a). Bilingualism in development: Language, literacy, and cognition. New York: Cambridge University Press.

Bialystok, E. (2001b). Metalinguistic aspects of bilingual processing. Annual Review of Applied Linguistics, 21, 169-181

Bialystok, E., Craik, F.I.M., Klein, R. and Viswanathan, M. (2004). Bilingualism, aging, and cognitive control: Evidence from the Simon task. Psychology and Aging 19, 2, 290-303.

Bialystok, E., and Ryan, E.B. (1985). Toward a definition of metalinguistic skill. Merrill Palmer Quarterly 31, 3, 229-251.

Burdach, A.M. et al. (1984). Los adjetivos deícticos temporales y su incidencia en la enseñanza de una segunda lengua. Revista de Lingüistica Teórica y Aplicada, $22,7-15$.

Burdach, A.M. et al. (1985). "Algunas consideraciones en torno a los adverbios deícticos temporales en ingles y español", Revista de Lingistica Teorica y Aplicada, 23, $163-173$.

Carbonero Cano, P. (1979). Deixis espacial y temporal en el lingüistico. Sevilla: Universidad de Sevilla.

Clark, E.V., \& Garnica, O. (1974). Is he coming or going? On the acquisition of deictic verbs. Journal of Verbal Learning and Verbal Behavior, 13, 559-572.

De Houwer, A. (1995). Bilingual language acquisition. In P. Fletcher \& B. MacWhinney (Eds.), The handbook of child language, 220-250. Oxford: Blackwell.

Dunn, L. [Lloyd] \& Dunn, D. (2007). Peabody Picture Vocabulary Test (PPVTTM_4). Pearson Education, Inc. 
Dunn, L. [Lloyd], , Lugo, D. Padilla, E. \& Dunn, [Leota]. (1981). Test de Vocabulario en Imágenes Peabody (TVIPTM). Pearson Education, Inc.

Fillmore, C. (1971). Santa Cruz lectures on deixis. Bloomington: Indiana University Linguistics Club.

Fillmore, C. (1981). How to know whether you're coming or going. In G. Rauh [Ed.], Essays on Deixis. Tubigen: Narr, 219-227.

Hernandez Pardo, M., A. Costa, and N. Sebastián-Gallés. (2008) The bilingual advantage inattentional control: Monitor and conflict resolution processes. Paper presented at international conference on models of interaction in bilinguals, October 24-26, in Bangor, Wales, UK.

Hockett, C.F. (1990). Bring, Take, Come, and Go. Journal of English Linguistics, 23, 239

Johnson, J. 1991. Cognitive processes in bilingualism and their cognitive growth effects. In Language processes in bilingual children, ed. E. Bialystok, 193-221. Cambridge: Cambridge University Press.

Molho, M. (1968). Remarques sur le système des mots démonstratifs en espagnol, Les Langues Modernes, 3, 46-62.

Moreno F., P. (1985). Deixis espacial en francés y en español. Revista de Lingüistica Teórica y Aplicada, 23, 157-162.

Richardson, B. (1996). Spanish spatial deictic features: indices of entities, location and movement. International Review Of Applied Linguistics In Language Teaching, 34, 3, 215-231.

Rodríguez-Izquierdo y Gavala, F.(1976). La deixis anafórica en el articulo español: comparación de textos de posesión y conversación. Revista Española de Lingüística 6, 1, 113-131. 
Appendix A - English/Spanish Bilingual Questionnaire as used in Gathercole et al.

Name:

Contact details / Address or phone number or email address:

\section{Questionnaire}

We would be grateful if you could give us the following background information to help us with our studies.

1. Are you: $\quad$ Male $\square$ Female $\square$ ?

2. Birthday:

3. Please tick your age range:

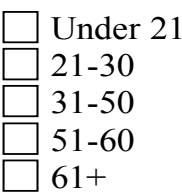

4. Were you born in the USA? Yes $\square$ No $\square$

If you were not born in the USA:

At what age did you move to the USA?

How many years have you lived in the USA?

Please indicate the areas where you have lived for significant periods (more than a year) of your life:

e.g.: Place: La Habana, Cuba Place: New York City, NY

Place: Miami, FA

Place:

Place:

Place:

Place:
Dates: 1975-93

Dates: 1993-99

Dates: 2002-05

Dates:

Dates:

Dates:

Dates: 
5. What is your heritage background?

$\square$ Cuban
$\square$ Puerto Rican
$\square$ Mexican
$\square$ Nicaraguan
$\square$ Argentinean
$\square$ Venezuelan
$\square$ Colombian
$\square$ Other Hispanic (please specify):
$\square$ Other non-Hispanic (please specify)

\section{Languages when you were a child:}

6. Which of the following languages do you speak? (Select all that apply and fill in the blanks)

Spanish I began speaking Spanish at around age:

$\square$ English I began speaking English at around age:

Other language(s): ___ I began speaking this language at around age:

7. What language(s) did your parents speak to you at home from birth until you turned about two years of age:

$\square$ Virtually $100 \%$ English

$\square$ About $80 \%$ English, 20\% Spanish

About 60\% English, 40\% Spanish

About 50\% English, 50\% Spanish

About $40 \%$ English, $60 \%$ Spanish

About 80\% English, 20\% Spanish

Virtually $100 \%$ Spanish

Other combination. Please specify:

8. What language(s) did your parents speak to you at home when you were a toddler (around two to four years of age):

$\square$ Virtually $100 \%$ English

About 80\% English, 20\% Spanish

About $60 \%$ English, $40 \%$ Spanish

About 50\% English, 50\% Spanish

About 40\% English, 60\% Spanish

About 80\% English, 20\% Spanish

Virtually $100 \%$ Spanish

Other combination. Please specify:

Page 2 


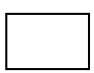

9. What language(s) did your parents speak to you at home when you were just starting school (around five to six years of age):

Virtually $100 \%$ English

About $80 \%$ English, 20\% Spanish

About 60\% English, 40\% Spanish

About 50\% English, 50\% Spanish

About 40\% English, 60\% Spanish

About 80\% English, 20\% Spanish

Virtually $100 \%$ Spanish

Other combination. Please specify:

10. What language(s) did your parents speak to you at home when you were in early primary school (seven to eight years of age):

Virtually $100 \%$ English

About 80\% English, 20\% Spanish

About 60\% English, 40\% Spanish

About 50\% English, 50\% Spanish

About 40\% English, 60\% Spanish

About 80\% English, 20\% Spanish

Virtually $100 \%$ Spanish

Other combination. Please specify:

11. What language(s) did your parents speak to you at home when you were in later school (around nine to twelve years of age):

Virtually $100 \%$ English

About 80\% English, 20\% Spanish

About 60\% English, 40\% Spanish

About 50\% English, 50\% Spanish

About 40\% English, 60\% Spanish

About 80\% English, 20\% Spanish

Virtually $100 \%$ Spanish

Other combination. Please specify:

If your mother and father did not speak the same language(s) to you, please elaborate on any differences in the language(s) your parents spoke to you when you were a child:

Page 3 
12. What language(s) did you speak to your parents when you were a child?
Virtually $100 \%$ English
About 80\% English, 20\% Spanish
About $60 \%$ English, 40\% Spanish
About 50\% English, 50\% Spanish
About $40 \%$ English, $60 \%$ Spanish
About 80\% English, 20\% Spanish
Virtually $100 \%$ Spanish
Other combination. Please specify:

13. What language(s) did your older siblings speak to you when you were a child? (If applicable)
Virtually $100 \%$ English
About 80\% English, 20\% Spanish
About 60\% English, 40\% Spanish
About 50\% English, 50\% Spanish
About 40\% English, 60\% Spanish
About 80\% English, 20\% Spanish
Virtually $100 \%$ Spanish
Other combination. Please specify:

14. What language(s) did your younger siblings speak to you by when you were a child? (If applicable)

Virtually $100 \%$ English

About $80 \%$ English, $20 \%$ Spanish

About $60 \%$ English, $40 \%$ Spanish

About 50\% English, 50\% Spanish

About $40 \%$ English, $60 \%$ Spanish

About 80\% English, 20\% Spanish

Virtually $100 \%$ Spanish

Other combination. Please specify: 


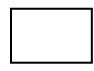

15. What language(s) did you speak to your older and younger siblings when you were a child? (If applicable)

Me to older siblings:

$\square$ Virtually $100 \%$ English

About $80 \%$ English, 20\% Spanish

About $60 \%$ English, $40 \%$ Spanish

About 50\% English, 50\% Spanish

About 40\% English, 60\% Spanish

$\square$ About $80 \%$ English, 20\% Spanish

$\square$ Virtually $100 \%$ Spanish

$\square$ Other combination. Please specify:

Me to younger siblings:

$\square$ Virtually $100 \%$ English

$\square$ About 80\% English, 20\% Spanish

$\square$ About $60 \%$ English, 40\% Spanish

About 50\% English, 50\% Spanish

$\square$ About 40\% English, 60\% Spanish

$\square$ About $80 \%$ English, 20\% Spanish

$\square$ Virtually $100 \%$ Spanish

$\square$ Other combination. Please specify:

16. Were there any other significant adults (grandparents, aunts, uncles...) with whom you had frequent contact as a child?

$\square$ Yes

$\square$ No

If yes, please specify their relation to you:

What language(s) did they speak to you?

Virtually $100 \%$ English

About $80 \%$ English, 20\% Spanish

About 60\% English, 40\% Spanish

About 50\% English, 50\% Spanish

About 40\% English, 60\% Spanish

About 80\% English, 20\% Spanish

Virtually $100 \%$ Spanish

Other combination. Please specify:

Page 5 
17. What was the normal language of instruction in the primary school that you attended?

$\square$ Virtually 100\% English
$\square$ About $80 \%$ English, 20\% Spanish
$\square$ About $60 \%$ English, 40\% Spanish
$\square$ About 50\% English, 50\% Spanish
$\square$ About $40 \%$ English, 60\% Spanish
$\square$ About $80 \%$ English, 20\% Spanish
$\square$ Virtually 100\% Spanish
$\square$ Other combination. Please specify:

18. What language(s) did you speak outside of the classroom at primary school?

$\square$ Virtually $100 \%$ English

$\square$ About $80 \%$ English, 20\% Spanish

About $60 \%$ English, $40 \%$ Spanish

About 50\% English, 50\% Spanish

About $40 \%$ English, $60 \%$ Spanish

$\square$ About $80 \%$ English, 20\% Spanish

$\square$ Virtually $100 \%$ Spanish

$\square$ Other combination. Please specify:

19. Overall, what language(s) did you speak with your friends when you were a child?

Virtually $100 \%$ English

About $80 \%$ English, 20\% Spanish

About 60\% English, 40\% Spanish

About 50\% English, 50\% Spanish

About 40\% English, 60\% Spanish

$\square$ About 80\% English, 20\% Spanish

$\square$ Virtually $100 \%$ Spanish

$\square$ Other combination. Please specify:

20. What was the normal language of instruction in the secondary school that you attended?

Virtually $100 \%$ English

About 80\% English, 20\% Spanish

About 60\% English, 40\% Spanish

About 50\% English, 50\% Spanish

About 40\% English, 60\% Spanish

About $80 \%$ English, 20\% Spanish

Virtually $100 \%$ Spanish

Other combination. Please specify: 
21. What was the normal language of instruction in the university or college that you attend(ed) (if applicable)?

Virtually $100 \%$ English

About 80\% English, 20\% Spanish

About 60\% English, 40\% Spanish

About 50\% English, 50\% Spanish

About 40\% English, 60\% Spanish

About 80\% English, 20\% Spanish

Virtually $100 \%$ Spanish

Other combination. Please specify:

\section{Languages used now}

\section{At present:}

I use Spanish at home approximately I use Spanish at work approximately In total, I speak Spanish approximately $\%$ of the time $\%$ of the time $\%$ of the time

I use English at home approximately I use English at work approximately $\%$ of the time In total, I speak English approximately $\%$ of the time

I use other languages at home approximately I use other languages at work approximately $\%$ of the time

In total, I speak other languages approximately

$\%$ of the time

$\%$ of the time $\%$ of the time

23. At present, my mother speaks to me in:

$\square$ Virtually $100 \%$ English

$\square$ About 80\% English, 20\% Spanish

About 60\% English, 40\% Spanish

About 50\% English, 50\% Spanish

About 40\% English, 60\% Spanish

About $80 \%$ English, 20\% Spanish

Virtually $100 \%$ Spanish

Other combination. Please specify: 
24. At present, my father speaks to me in:

$\square$ Virtually $100 \%$ English

About 80\% English, 20\% Spanish

About 60\% English, 40\% Spanish

About 50\% English, 50\% Spanish

About 40\% English, 60\% Spanish

About 80\% English, 20\% Spanish

Virtually $100 \%$ Spanish

Other combination. Please specify:

25. At present, my siblings and I speak to each other in: (if applicable)

$\square$ Virtually $100 \%$ English

About 80\% English, 20\% Spanish

About 60\% English, 40\% Spanish

About 50\% English, 50\% Spanish

About 40\% English, 60\% Spanish

About 80\% English, 20\% Spanish

Virtually $100 \%$ Spanish

$\square$ Other combination. Please specify:

26. At present, my friends and I speak to each other in:

Virtually $100 \%$ English

About 80\% English, 20\% Spanish

About 60\% English, 40\% Spanish

About 50\% English, 50\% Spanish

About 40\% English, 60\% Spanish

About 80\% English, 20\% Spanish

Virtually $100 \%$ Spanish

Other combination. Please specify:

Page 8 


\section{Views on language}

27. On a scale of 1 to 4 , how well do you feel you can ...?

Understand Spanish now:

$\square 1$ Can understand basic words and expressions

$\square 2$ Can understand simple conversations

$\square 3$ Can understand extended conversations

4 Can understand virtually any kind of conversation

Speak Spanish now:

$\square 1$ Only know basic words and expressions

$\square 2$ Can carry out simple conversations

3 Can carry out extended conversations

$\square 4$ Can carry out virtually any kind of conversation

Read Spanish now:

$\square 1$ Can read basic words and expressions

$\square 2$ Can read simple texts

$\square 3$ Can read extended texts

$\square 4$ Can read virtually any kind of text

\section{Write Spanish now:}

1 Can write basic words and expressions

2 Can write simple texts

$\square 3$ Can write extended texts

4 Can write virtually any kind of text

28. On a scale of 1 to 4 , how well do you feel you can...?

Understand English now:

$\square 1$ Can understand basic words and expressions

$\square 2$ Can understand simple conversations

$\square 3$ Can understand extended conversations

4 Can understand virtually any kind of conversation 
Speak English now:

1 Only know basic words and expressions

2 Can carry out simple conversations

3 Can carry out extended conversations

$\square 4$ Can carry out virtually any kind of conversation

Read English now:

$\square 1$ Can read basic words and expressions

$\square 2$ Can read simple texts

3 Can read extended texts

$\square$ Can read virtually any kind of text

Write English now:

1 Can write basic words and expressions

$\square 2$ Can write simple texts

$\square 3$ Can write extended texts

$\square 4$ Can write virtually any kind of text

29. How important is it to you to know Spanish?

$\square$ Extremely important

$\square$ Very important

$\square$ Somewhat important

$\square$ Not important

30. How important is it to you to know English?

Extremely important

Very important

$\square$ Somewhat important

$\square$ Not important

31. How important was it for your parents that you learned Spanish?

Extremely important

Very important

Somewhat important

$\square$ Not important 
32. How important was it for your parents that you learned English?
Extremely important
Very important
Somewhat important
Not important

\section{General information}

33. Please indicate the highest level of education completed by you:

$\square$ Primary education up to year

Secondary education up to year

University or college education up to year or degree:

Major:

Post-graduate education up to year or degree:

None of the above

34. Please indicate the highest level of education completed by your mother:

$\square$ Primary education up to year

Secondary education up to year

University or college education up to year or degree:

Major:

Post-graduate education up to year or degree:

None of the above

35. Please indicate the highest level of education completed by your father:

$\square$ Primary education up to year

Secondary education up to year

University or college education up to year or degree:

Major:

Post-graduate education up to year or degree:

None of the above

36. What is your present occupation (or if retired or unemployed, what was your last occupation before retiring or becoming unemployed)?

37. What was your mother's occupation when you were a child?

Page 11 
38. Has your mother always resided in Miami? $\square$ Yes $\square$ No If not, please indicate where else she has lived And when

39. Please indicate approximately when your mother began to speak Spanish: Age

40. Please indicate approximately when your mother began to speak English : Age

41. What was your father's occupation when you were a child?

42. Has your father always resided in Miami? $\square$ Yes $\square$ No

If not, please indicate where else he has lived And when

43. Please indicate approximately when your father began to speak Spanish: Age

44. Please indicate approximately when your father began to speak English : Age

45. What is your partner's present occupation (if applicable)?

46. Do you rent or own you current residence?

$\square$ Rent

Own

47. Have you ever undergone speech or language therapy?

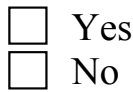

48. Have you ever been treated for a hearing problem?

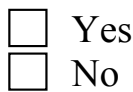

49. Have you ever been treated for a vision problem?

$\square$ Yes

Thank you very much for your time and co-operation

Page 12 
Appendix B - Monolingual Questionnaire as adapted from Yavas, M.

\section{Language History Questionnaire}

Name:

Email:

Telephone: (_

Today's Date:

1. Age:

2. Date of Birth

2. Sex: Male _ Female

3. Education (highest degree obtained or school level attended) by you:

Some high school

Completed high school or equivalent GED

Some college

Completed college or university

Major:

Some graduate or professional school

Completed graduate or professional school

Degree obtained:

4. Country of origin:

5. Were you born in the USA? Yes No

If no, at what age did you move to the USA?

How many years have you lived in the USA?

6. Country of residence:

8. Please indicate the highest level of education completed by your father: 
Primary education up to year

Secondary education up to year

University or college education up to year or degree:

Major:

Post-graduate education up to year or degree:

None of the above

9. Please indicate the highest level of education completed by your mother:

Primary education

Secondary education University or college education

Major:

Post-graduate education None of the above

10. What is your present occupation (or if retired or unemployed, what was your last occupation before retiring or becoming unemployed)?

11. What was your mother's occupation when you were a child?

12. Would you be willing to be contacted for further language studies? Yes No up to year or degree:

up to year or degree: 